Przegląd Filozoficzny - Nowa Seria

R. 21: 2012, Nr 1 (81), ISSN 1230-1493

DOI: $10.2478 / \mathrm{v} 10271-012-0001-\mathrm{x}$

Tego nie można przeoczyć

\author{
J a n W o le ńs ki
}

\title{
Nowy wspaniały (filozoficzny) świat poprawiony, czyli refleksje o Encyklopedii filozofii polskiej
}

Encyklopedia filozofii polskiej, pod red. Andrzeja Maryniarczyka; redaktorzy działów: Marian Ciszewski (filozofia renesansu), Honorata Jakuszko (filozofia nowożytna), Stanisław Janeczek (filozofia oświecenia), Piotr Jaroszyński (filozofia kultury), Henryk Kiereś (filozofia sztuki, filozofia poznania), Małgorzata Kowalewska (filozofia współczesna), Andrzej Maryniarczyk (metafizyka, antropologia), Marcin Tkaczyk (logika), Agnieszka Lekka-Kowalik (metodologia nauk), Zenon E. Roskal (filozofia przyrody), Kazimierz Wójcik (filozofia średniowieczna), Katarzyna Stępień (filozofia prawa), Zofia J. Zdybicka (filozofia Boga i religii); konsultacja merytoryczna Antoni B. Stępień; tom 1: A-L, ss. 957; tom 2: M-Ż, ss. 947, Polskie Towarzystwo Tomasza z Akwinu, Lublin 2011

Tekst ten nie jest recenzją w zwyczajowym sensie, bo nie jest rzeczą możliwa, aby jeden autor napisał takową. Encyklopedia filozofii polskiej (dalej: Encyklopedia) liczy blisko dwa tysiące dwuszpaltowych stron, zawiera około 950 haseł, napisanych przez prawie 200 autorów. Wiele haseł pokrywa się (lub stanowi ich rozwinięcie) z opublikowanymi wcześniej w Powszechnej encyklopedii filozofii (dalej: PEF), także wydanej przez Polskie Towarzystwo Tomasza z Akwinu, rozpoczętej w 2000 r., a zakończonej dziewięć lat później; 
ogółem ukazało się dziesięć tomów, w tym ostatni jako Suplement. Encyklopedie te wyglądają bardzo efektownie z zewnątrz, ale gorzej jest z drukiem, który mógłby być bardziej skontrastowany z białym tłem. Obu brakuje szczegółowych indeksów rzeczowych i osobowych. W PEF brak ten jest nieco kompensowany wykazem haseł poświęconych poszczególnym myślicielom (z krótkimi streszczeniami) oraz słownikiem pojęć. Tego nie ma Encyklopedia. Posiada ona, podobnie jak PEF, indeks haseł i indeks autorów, ale bez informacji, co napisali i jakie mają (lub mieli, bo niektórzy zmarli) afiliacje. Te niedostatki utrudniają korzystanie z obu encyklopedii, a zwłaszcza ich recenzowanie czy też nawet tylko omawianie. Chciałbym np. wiedzieć, ile haseł napisali autorzy z kręgu, w którym powstała Encyklopedia, a ile inni, a także czego one dotyczyły. Mógłbym oczywiście sprawdzić i policzyć, ale szkoda czasu na taką buchalterię. Zważywszy na deklarowaną rangę obu przedsięwzięć, wydawcy powinni byli zadbać o lepszą redakcję. Kwestia afiliacji jest ważna, ponieważ, jak to dalej pokażę na konkretnych przykładach, niektórzy autorzy związani ze środowiskiem, w którym powstała Encyklopedia, bardzo szczególnie rozumieli swą rolę encyklopedystów.

Zgodnie z tytułem, formułuję garść refleksji o Encyklopedii. Dotyczą one przede wszystkim obrazu współczesnej filozofii polskiej, wyłaniającego się z tego dzieła, a tylko sporadycznie innych kwestii. Moje uwagi są krytyczne, niektóre nawet bardzo. Trochę mi z tym nieswojo, ponieważ sam napisałem trzy hasła, mianowicie o Marianie Przełęckim, szkole lwowsko-warszawskiej i Kazimierzu Twardowskim (wszystkie ukazały się wcześniej w PEF). Mówiąc ogólnie, konterfekt przedmiotu Encyklopedii jest przez nią mocno zdeformowany i wielce stronniczy względem rzeczywistego stanu rzeczy. W szczególności (rozwinę to $\mathrm{w}$ dalszych partiach tekstu) współczesna myśl polska, zwłaszcza po roku 1945, a jeszcze bardziej obecna, jest pokazana jako podzielona na katolicką i resztę, przy czym polska filozofia katolicka w zasadzie sprowadza się do neotomizmu, a tzw. szkoła lubelska, związana z Katolickim Uniwersytetem Lubelskim, stanowi centrum tego ruchu. Nie mam zamiaru kwestionować pozycji „lublinian” w polskim ruchu neoscholastycznym. Wszelako polskie proporcje filozoficzne są tak ułożone w Encyklopedii, że nasza filozofia jest podzielona na lubelską (ewentualnie, okołolubelską) i pozalubelską. Optyka ta w niejednym przypadku decyduje o doborze haseł rzeczowych i osobowych, a także ocenach i interpretacjach formułowanych w Encyklopedii. Dotyczy to przede wszystkim niektórych tekstów napisanych przez autorów lubelskich lub osoby o podobnych poglądach. Formułuję to ostrożnie, przy użyciu małego kwantyfikatora „niektórych”. Dokładniejsze oszacowanie wymagałoby zbadania wszystkich haseł na temat współczesnej filozofii polskiej i porównania ich z tymi, które wyszły spod pióra autorów należących do innych środowisk. Na podstawie mojej lektury mogę jednak stwierdzić, 
że fragmentów naznaczonych ponad miarę piętnem przynależności do lubelskiego (w szerokim sensie) ośrodka filozoficznego jest niemało. Formułując jaką́ ocenę ogólną i z zamierzoną przesadą, czytelnik może odnieść wrażenie, że „pozalubelska” filozofia polska jest tylko dodatkiem do lubelskiej, która sama siebie mianowała najważniejszą kontynuatorką tzw. filozofii klasycznej, tj. arystotelesowsko-tomistycznej. Nie jest to pierwszy przypadek przedstawiania takiego właśnie ujęcia współczesnej myśli filozoficznej pochodzący ze środowiska reprezentowanego przez redaktora naczelnego, redaktorów poszczególnych działów i konsultanta merytorycznego, ponieważ podobnie rzecz ma się w haśle „Poland, Philosophy of” w The Routledge Encyclopedia of Philosophy (1998), napisanym przez Jana Czerkawskiego, Antoniego B. Stępnia i Stanisława Wielgusa. Poddałem krytyce ten tekst w szkicu $W$ sprawie historii filozofii w Polsce, „Ruch Filozoficzny” LV (4) (1998), s. 559-566. Uwagi niniejsze mogą być traktowane jako kontynuacja tych sprzed dwunastu lat. W obu wypadkach mamy do czynienia z produktem określonym przez preferencje wypływające $\mathrm{z}$ wyraźnego interesu historycznego i perswazyjno-propagandowego, mniejsza o to, czy świadomego, czy funkcjonującego tylko w tle. Encyklopedia promuje szkołę lubelską i jej tradycję jako miernik wartości filozofii polskiej. I to mam zamiar okazać w dalszym ciagu niniejszego tekstu.

Nim przejdę do uzasadnienia swojej oceny, poczynię parę uwag ogólnych, niezależnych od głównego zamysłu niniejszego omówienia. Nie jest oczywiście tak, że Encyklopedia zasługuje wyłącznie na krytykę. Jeszcze raz powtarzam, że jest to przedsięwzięcie monumentalne co do objętości i zakresu. Nie ma precedensu w dotychczasowej polskiej literaturze filozoficznej, a należy sądzić, że nieprędko zostanie zastapione przez podobne opracowanie, o ile w ogóle stanie się to w przyszłości. Encyklopedia zawiera mnóstwo materiału faktograficznego i ikonograficznego (redakcja dotarła np. do wielu nieznanych zdjęć) na temat filozofów polskich z różnych epok. Prezentacje poglądów poszczególnych myślicieli dostarczają cennych informacji, trudnych do znalezienia w innych wydawnictwach. Interesującym pomysłem są hasła rzeczowe dotyczące problemów i instytucji filozoficznych. Sam wielce żałuję, że Encyklopedia nie ukazała się wcześniej, gdyż znacznie ułatwiłaby pracę nad Historiq filozofii polskiej (Wydawnictwo WAM, Kraków 2010), książki napisanej przeze mnie i Jana Skoczyńskiego. Redaktorzy zdecydowali się na zamieszczenie haseł o mniej znanych i niezbyt znaczących filozofach dawnych i współczesnych z nieodległej przeszłości, a w ten sposób zapewne ocalili ich od całkowitego zapomnienia. Nie ma wątpliwości, że Encyklopedia odegra znaczną rolę w utrwaleniu tego, co można nazwać polską pamięcią filozoficzną. Gdybym pisał recenzję w normalnym znaczeniu, na pewno podkreśliłbym te wartości szerzej, a przede wszystkim szczegółowo. 
Ma też Encyklopedia braki zawsze zdarzające się w tego rodzaju wydawnictwach, np. przeoczenia. Tym tłumaczyłbym brak haseł (lista jest na pewno niekompletna, zapewne dyktowana kryteriami subiektywnymi w pewnych przypadkach i ogranicza się tylko do XX w.) poświęconych następującym (nieżyjącym od dłuższego lub krótszego czasu, o żyjących będzie mowa później) osobom: Franciszek Baron (estetyk), Eugeniusz Bautro (prawnik), Paulin Chomicz (neomesjanista), Zbigniew Czerwiński (metodolog nauk), Samuel Dickstein (matematyk), Dawid Einhorn (historyk filozofii), Stanisław Ehrlich (teoretyk prawa), Eugenia Ginsberg-Blausteinowa (znawczyni fenomenologii), Władysław Hetper (logik), Irena Filozofówna (autorka książki o propedeutyce filozofii), Maria Jędrzejowska (estetyk), Jan Karłowicz (językoznawca), Jakub Karpiński (socjolog, metodolog nauk społecznych), Aleksander Kielski (metodolog nauki), Zdzisław Kraszewski (logik), Helena Leleszówna (psycholog), Jan Lutyński (etnolog), Zbigniew Majewski (filozof fizyki), Juliusz Makarewicz (prawnik), ks. Witold Michałowski (historyk logiki), Mieczysław Milbrandt (historyk filozofii), Jan Mosdorf (historyk filozofii), Stefan Nowak (socjolog, metodolog nauk społecznych), Czesław Nowiński (dawniej Sawa Frydman, filozof prawa i epistemolog), Ostap Ortwin (estetyk), Antoni Pański (metodolog nauki), Józef Pepis (logik), Aleksander Peczenik (teoretyk i filozof prawa), Antoni Peretiatkowicz (teoretyk prawa), Adam Podgórecki (socjo$\log$ i metodolog nauki), Halina Poświatowska (poetka, absolwentka filozofii), ks. Leopold Regner (logik i historyk logiki), Witold Rudziński (wcześniej Witold Steinberg: filozof prawa), Andrzej Siemianowski (metodolog nauki), Wacław Sierpiński (matematyk), Helena Słoniewska (psycholog), Stanisław Szober (językoznawca), Witold Wilkosz (matematyk i logik), Jerzy Wróblewski (filozof prawa), Bronisław Wróblewski (prawnik), Aleksander Wundheiler (metodolog nauki) czy Józef Zajkowski (filozof prawa).

Trudno przypuścić, aby wyżej wymienione osoby zostały pominięte świadomie (niektóre $\mathrm{z}$ tych nazwisk pojawiają się zresztą $\mathrm{w}$ innych hasłach, a więc nie są nieznane redaktorom całego przedsięwzięcia), skoro są porównywalne pod względem znaczenia, dorobku czy aktywności z wieloma filozofami uwzględnionymi w Encyklopedii (np. skoro jest Kazimierz Opałek czy Wacław Makowski, to dziwi brak J. Wróblewskiego czy J. Makarewicza; pierwszy był równie wybitnym teoretykiem prawa, rangi światowej, jak Opałek, a drugi napisał ważniejsze dzieło z filozofii prawa karnego niż Makowski, cenione w literaturze niemieckiej). Niektórzy z nieobecnych i wyżej wymienionych (W. Michałowski, L. Regner, A. Siemianowski) byli filozofami katolickimi, a kilku innych (Z. Kraszewski, Z. Majewski, Cz. Nowiński) odegrali pewną rolę (Kraszewski, Majewski) lub nawet dużą (Nowiński) w filozofii marksistowskiej, zaś Encyklopedia poświęca tym nurtom bardzo wiele miejsca, więcej niż jakimkolwiek innym. Encyklopedia uwzględnia także przedstawicieli 
środowiska literackiego, zarówno twórców, jak i krytyków. Można dyskutować nad doborem nazwisk, np. nieobecni są wybitni polscy poeci XX w., jak np. Bolesław Leśmian, klasyk realizmu magicznego, czy Leopold Staff (tłumacz dzieł Nietzschego). Jedno pominięcie, mianowicie Tadeusza Boya-Żeleńskiego, wybitnego thumacza $\mathrm{z}$ języka francuskiego, także literatury filozoficznej $\mathrm{i}$ to klasycznej, nie wygląda na przypadek czy zwyczajne niedopatrzenie. Boy miał wiele do powiedzenia w kwestiach moralno-obyczajowych, a także miał swoją koncepcję kultury. Skoro w Encyklopedii znalazło się miejsce dla Zofii Kossak-Szczuckiej czy Kazimierza Wyki, trudno zrozumieć, dlaczego zabrakło go dla Boya-Żeleńskiego. Czyżby zadecydował jego radykalny antyklerykalizm? Można też mieć zastrzeżenia co do kształtu pewnych haseł czy informacji w nich zawartych. Jest mowa o antyindukcjonizmie Łukasiewicza, aczkolwiek warto by opracować temat ogólniejszy, mianowicie indukcjonizm i antyindukcjonizm w Polsce. Brakuje hasła o Braciach Polskich (pominięci są także wybitni przedstawiciele tego ruchu, jak obaj Stegmanowie - starszy i młodszy, obaj nosili imię Joachim - i Samuel Przypkowski), Młodej Polsce, polskiej filozofii narodowej (jest o mesjanizmie, ale to nie to samo), polskiej szkole filozofii medycyny, pozytywizmie warszawskim (zwanym też polskim), warszawskiej szkole historii idei czy krakowskiej szkole filozofii przyrody, zarówno dawniejszej, jak i nowszej, a także o filozofii polskiej na emigracji w XX w. O hasłach rzeczowych będzie jeszcze mowa dalej, a więc na razie poprzestaję na tych kilku przykładach.

A teraz kilka uwag o niektórych (w sumie niewielu; inne będą komentowane dalej) hasłach. W haśle „Towarzystwa i instytucje filozoficzne w Polsce" (t. 2, s. 739; autorka: A. Czajczyk) podana jest informacja, że PEF jest pierwszym w Polsce i trzecim na świecie dziełem tego typu. Ta druga wiadomość jest zdecydowanie nieprawdziwa. W mojej prywatnej bibliotece znajdują się (mowa tylko o wielotomowych, aczkolwiek mniej niż 10-tomowych) trzy encyklopedie amerykańskie, dwie niemieckie, jedna francuska i jedna rosyjska. Wiadomo mi, że jest także włoska i druga rosyjska. Wszystkie zostały wydane przed PEF, a więc jest ona w najlepszym wypadku siódma w kolejności, a pewnie nie wiem o wszystkich. W haśle „Mesjanizm” (t. 1, s. 107; autorka: T. Zawojska) utrzymuje się, że mesjanizm „był programowo przemilczany” w czasie „rządów komunistycznych”. Autorka chyba nie dostrzega własnej niekonsekwencji, skoro cytuje kilka prac wydanych w latach 70. i 80. XX wieku. Janusz Korczak został przedstawiony jako człowiek głęboko religijny (t. 1, s. 714; autor: E. Mitek). Wiadomo jednak, że poglądy Korczaka na religię były niejednoznaczne i zmieniały się w czasie. O Andrzeju FryczuModrzewskim czytamy (t. 1, s. 182; autor: A. Kaim), że „nigdy nie odstapił od Kościoła katolickiego i nigdy nie opowiedział się za reformacją". Pewnie dlatego Pius IV zażądał od bp. Karnkowskiego usunięcia Modrzewskie- 
go, ,jako niebezpiecznego heretyka” (m.in., bo chodziło także o ślub osoby mającej święcenia kapłańskie), ze stanowiska wójta we Wolborzu. Podobnie wyretuszowani są Jan Kochanowski (nic o sympatiach w kierunku reformacji, poza ogólnikową wzmianką, że był inspirowany chrześcijaństwem), Hugo Kołłątaj (nic o okresie deistycznym w jego poglądach), Ignacy Krasicki (nic o jego ostrej krytyce duchowieństwa) czy Stanisław Staszic, na którego, wedle Encyklopedii, pozytywnie wpłynęła narodowa tradycja religijna, a negatywnie oświeceniowa. Wystapienie Jana Baudouina de Courtenaya z Kościoła katolickiego jest komentowane (t. 1, s. 83; autor: R.T. Peszek) jako motywowane niechęcią do „wszelkich zbiorowych form życia społecznego". Autor powiada „wydaje się", a więc sam przyznaje, że nie wie dokładnie, jakie były motywy Baudouina de Courtenaya, ale jednak wyraża taką opinię.

O Stefanie Żeromskim czytamy (t. 2, s. 909; autor: P. Jaroszyński):

humanista, pisarz na wskroś pol., mimo sympatii do socjalizmu, nigdy nie posunął się do doktrynerstwa, dla którego poświęciłby niepodległość ojczyzny czy (zwł. w ostatnim etapie życia) chrześcijaństwo, w klimacie którego wzrastał i do którego pod koniec życia wracał.

Nie bardzo wiadomo, po pierwsze, dlaczego Jaroszyński utrzymuje, że sympatia do socjalizmu, nawet naznaczona doktrynerstwem, miałaby prowadzić do poświęcenia niepodległości ojczyzny (wniosek na temat poświęcania chrześcijaństwa przez socjalistów jest nawet zabawny), a po drugie, nie jest jasne, co to znaczy, że ktoś wracał do chrześcijaństwa. Wracał czy wrócił? Warto by opinię na ten temat jakoś udokumentować. Dokładniejsza lektura dostarczyłaby zapewne więcej przykładów filtrowania doboru nazwisk i zastosowanych interpretacji przez katolicką optykę, ale, jeszcze raz powtarzając, że nie jest to recenzja, nie będę kontynuował tego wątku wobec przeszłości. Może tylko zaznaczę na podstawie wyrywkowej lektury Encyklopedii, że autorzy związani ze szkołą lubelską wykazują szczególną predylekcję do rozpatrywania poglądów przez siebie omawianych z punktu widzenia filozofii katolickiej. Oto wyrazisty przykład. O Tadeuszu Kotarbińskim mamy dwa hasła, jedno ogólne (t. 1, s. 726-731; autor: W. Gasparski) i drugie poświęcone wyłącznie etyce niezależnej (t. 1, s. 359-361; autor: K. Krajewski). W tym pierwszym także znajdujemy całkiem spory fragment o poglądach etycznych Kotarbińskiego. Omówienie tematu w obu hasłach jest w dużej mierze zbieżne, a więc niejako dziwi to, że idee etyczne Kotarbińskiego wymagały dodatkowego omówienia. Rzecz wyjaśnia się, gdy zważymy, że redaktorzy Encyklopedii uznali za potrzebne, aby doktryna ta została poddana krytyce. Pierwsze hasło jest czysto opisowe i w ogóle nie zawiera akcentów krytycznych, natomiast w drugim pojawia się krytyka, nawet $\mathrm{w}$ dwóch odrębnych fragmentach, $\mathrm{z}$ których jeden 
jest zatytułowany „Krytyka etyki niezależnej przez etyków chrześcijańskich” (nawiasem mówiąc, winno być „katolickich”, bo tylko o nich jest mowa). Jest rzeczą zdumiewająca, że autor hasła w encyklopedii powszechnej (bo Encyklopedia jest tak przedstawiana) w krytyce referuje swoje własne zastrzeżenia (chyba tak, skoro nie podaje żadnej dokumentacji) w ramach krytyki ogólnej, a potem doprawia to uwagami z punktu widzenia światopoglądu, który sam reprezentuje. $Z$ neutralnego punktu widzenia, a taki właśnie przystoi encyklopediom powszechnym, krytyka chrześcijańska nie ma żadnego wyróżnionego znaczenia.

Wprawdzie, jak zaznaczyłem, zajmuję się w niniejszych uwagach obrazem filozofii polskiej w Encyklopedii, nie mogę się jednak powstrzymać od pewnej uwagi systematycznej. Na s. 63 w t. 2 (hasło „Marksistowski materializm”, aczkolwiek tytuł nie ma znaczenia dla moich uwag; autor: A.B. Stępień) znajdujemy polemikę z pewnymi argumentami przeciwko dowodowi z przyczyny sprawczej na istnienie Boga. Oto stosowny cytat:

[...] argumentację B. Russella. Jeśli każdy byt ma swoją przyczynę, to dlaczego nie pytamy o przyczynę Boga? Ten argument bierze się z nietrafnej filozoficznej koncepcji przyczyny (związku przyczynowego) oraz $\mathrm{z}$ niewłaściwego zrozumienia sposobu, w jaki na terenie filozofii bytu (metafizyki) dochodzi się do uznania istnienia osobowego Absolutu. Przez przyczynę rozumiemy tu zewnętrzną rację dostateczną istnienia bytu, a zasada przyczynowości (sprawczej) głosi, że każdy byt, który nie istnieje dzięki sobie (a więc jest przygodny, niekonieczny), ma zewnętrzną rację swego istnienia. Ostatecznie musi nią być byt, który istnieje dzięki sobie (a więc nie wymaga $z$ kolei innej zewnętrznej racji swojego istnienia, byt konieczny, pierwotny). Pytanie o przyczynę (a więc zewnętrzną rację) takiego bytu jest nietrafne i bezzasadne.

Nie znam wszystkich wypowiedzi Russella na temat przyczynowości i Boga, więc nie ręczę, czy nie napisał gdzieś, że skoro ktoś twierdzi, że każdy byt ma swoją przyczynę, to powinno się także pytać o przyczynę Boga. Niezależnie do tego, czy Russell takie zagadnienie postawił, czy nie, miał on znacznie poważniejsze argumenty w kwestii dowodu z przyczyny sprawczej. W znanej polemice z o. F. Coplestonem (emitowanej przez BBC w 1948 r.) Russell zauważył, że pierwszy dowód Akwinaty przypomina rozumowanie, że skoro każdy człowiek ma matkę, to istnieje matka wszystkich ludzi. Chodzi zaś o to, że wniosek ,istnieje przyczyna wszystkich bytów" nie wynika logicznie z przesłanki „każdy byt ma swoją przyczynę”, podobnie jak zdanie ,istnieje największa liczba naturalna” nie wynika ze zdania „dla każdej liczby, istnieje liczba od niej większa”. W ogólności, zdanie ,istnieje takie $y$, że dla każdego $x, P(x, y)$ " nie wynika logicznie ze zdania "dla każdego $x$, istnieje takie $y$, że $P(x, y)$ " (wyrażenie $P(x, y)$ czytamy: ,x jest skutkiem $y$ ", tj. $y$ jest przyczyną $x$ ). Russell zwrócił też uwagę na to, iż przyjęcie nieskończonego ciąu 
(zarówno wstecznego, jak i prospektywnego) przyczyn i skutków nie prowadzi do sprzeczności. Jeśli zaś przyjąć argument zawarty w zacytowanym tekście, to termin ,przyczyna” ma inne znaczenie w przesłance, a inne we wniosku, niezależnie od tego, że znawca pism Romana Ingardena, a za takiego podaje się Stępień, winien być co najmniej ostrożny w identyfikacji zasady przyczynowości i zasady racji dostatecznej. Byłoby też wskazane, aby tomiści z Lublina nie reklamowali swoich rozstrzygnięć metafizycznych jako uniwersalnych i niepodważalnych prawd. Bywa, że kto innych uważa za tak głupich, jak sam o sobie sądzi, że jest mądry, popada w zgoła przeciwne położenie.

Dobrym przejściem do dalszych uwag jest sprawa nawrócenia się Kotarbińskiego. W haśle o tym filozofie w PEF (t. 5, s. 907; nota umieszczona po haśle) czytamy:

OD REDAKCJI: Uzupełniając informacje o życiu T. Kotarbińskiego należy odnotować, że w ostatnich dniach swego życia świadomie i dobrowolnie przyjął sakrament namaszczenia chorych wraz z papieskim błogosławieństwem na godzinę śmierci. Sakramentu tego udzielił ks. J. Bazarnik, kapelan w Instytucie Kardiologii w Warszawie, poświadczając o tym fakcie na piśmie. Dokument ten został przekazany do tworzonego archiwum Kotarbińskiego, natomiast kopia poświadczona notarialnie znajduje się w Redakcji PEF.

Nota ta została pominięta w Encyklopedii. Powstaje naturalne pytanie, skąd ta zmiana, tj. dlaczego zrezygnowano z informacji o nawróceniu Kotarbińskiego, niejako sztandarowego ateisty polskiego i symbolu niezależności od religii, tym bardziej, że w publicystycznych omówieniach PEF (patrz niżej, gdzie cytowana jest wypowiedź A. Maryniarczyka w „Naszym Dzienniku”) rzecz ta była bardzo mocno podkreślana i to $\mathrm{z}$ niekłamaną satysfakcją. Początkowo sądziłem, że redaktorzy zastosowali argumentum ex silentio z uwagi na komentarze (patrz niżej) w rzeczonej sprawie. Otrzymałem jednak wyjaśnienie od redaktora naczelnego Encyklopedii (list z 15.11.2011 r.; jest to odpowiedź na moją listowną uwagę w sprawie hasła o Kotarbińskim w PEF). Oto ono:

Jeśli zaś chodzi o „casus” Kotarbińskiego, to niestety muszę zmartwić Pana Profesora. Brak uzupełnienia od redakcji jest niezamierzony. Łamaczowi tekstu umknął oddzielny plik, co nie zostało zauważone przy sprawdzaniu szpalt i wychwycone. Dziękuję za zwrócenie na to uwagi.

Ponieważ nie czuję się w najmniejszym stopniu zmartwiony zaistniałą sytuacją, ks. A. Maryniarczyk nie musi się niepokoić skutkami swojej informacji. Ważniejsze jest to, że dalej podtrzymuje to, co łamacz nieopatrznie opuścił.

Przytoczę teraz zapowiedziane uzupełnienie (może służyć jako komentarz) do informacji o przyjęciu sakramentów przez Kotarbińskiego (za „Res Humana" 2011, 2-3): 
Inspiracją, a zarazem podstawą tej noty [w Encyklopedii - J.W.] jest oświadczenie ks. Jacka Bazarnika, obecnie kapelana Instytutu-Szpitala Pomnika Centrum Zdrowia Dziecka w Warszawie-Międzylesiu, a wówczas tego duchownego, który w Instytucie Kardiologii w Aninie miał Tadeuszowi Kotarbińskiemu, w przeddzień Jego śmierci, udzielić wspomnianego „sakramentu namaszczenia chorych”. Poniżej drukujemy tekst tego oświadczenia, napisanego 3 grudnia 2003 roku dla Powszechnej Encyklopedii Filozofii i dla mgr Adama Szpaderskiego, autora wcześniej napisanego i wycofanego tekstu o Tadeuszu Kotarbińskim dla tej encyklopedii.

„Ksiądz Jacek Bazarnik, kapelan Instytutu-Szpitala „Pomnika Centrum Zdrowia Dziecka" w Warszawie-Międzylesiu.

W czasie mojej pracy duszpasterskiej w W-wie Aninie w latach 1978-1982 zostałem przez Księdza Proboszcza oddelegowany do pracy w Instytucie Kardiologii w W-wie. Instytut przejmował wtedy budynki szpitalne po Lecznicy Rządowej. Za pozwoleniem władz Instytutu założyłem Kaplicę Szpitalną i systematycznie odwiedzałem poszczególne oddziały szpitala, przynosząc chorym pociechę duchową i udzielając Sakramentów Kościoła. Na przełomie września i października 1981 r., odwiedzając Oddział Intensywnej Opieki, spotkałem ciężko chorego, starszego człowieka. Tego dnia był nieprzytomny albo mocno spał po przyjęciu środków znieczulających. Następnego dnia był przytomny. Miał pełnię świadomości, że jest przy nim ksiądz katolicki. Przedstawiłem się i wyraziłem swoje współczucie z racji jego cierpień. Wtedy dowiedziałem się, że jest filozofem i twórcą etyki świeckiej. Domyśliłem się, kim jest mój pacjent. Potem lekarz dyżurny dr Marek Dąbrowski potwierdził, że to Profesor Tadeusz Kotarbiński. Kolejnego dnia Pan Profesor był również przytomny. Poznał mnie i powitał serdecznym uśmiechem. Ponieważ studiowałem przez dwa lata filozofię w Metropolitalnym Seminarium Duchownym w W-wie, tego właśnie dnia zacytowałem z pamięci pewne piękne określenia z twórczości Pana Profesora. Wyraźnie był tym poruszony. A potem powiedziałem, że jest ze mną Ukryty Pan Jezus i gorąco modlę się, aby Panu Profesorowi przyniósł ulgę w cierpieniu. Pan Profesor z trudem powiedział mi, że był wychowany w rodzinie głęboko katolickiej, ale w pewnym momencie młodego życia stracił wiarę. Wtedy zacytowałem słowa Ewangelii: ...że u Boga ostatni będą pierwszymi, a pierwsi ostatnimi... i że Bóg jest Miłością! Panu Profesorowi popłynęły łzy z oczu. Ponieważ miałem pewność, że jest ochrzczony, pochyliłem się nad nim, zachęcając do ufności w Miłosierdzie Boże. Zaproponowałem Mu warunkowe rozgrzeszenie i Sakrament Chorych. Wyciagnął do mnie swe dłonie i ja namaściłem je Olejem Chorych, udzielając Błogosławieństwa Papieskiego z Odpustem Zupełnym. Na koniec ucałowałem Pana Profesora w czoło, a On ogarnął mnie swymi ramionami i mocno przytulił. Na drugi dzień poinformowano mnie, że Pan Profesor Tadeusz Kotarbiński nie żyje. [...] Warszawa, 3.XII.2003 r. Ks. Jacek Bazarnik"

Zarówno oświadczenie ks. Jacka Bazarnika, jak i nota od redakcji Powszechnej Encyklopedii Filozofii zostały skomentowane. Oto te komentarze.

1. W trzeciej części trzyodcinkowego eseju Magdaleny Grochowskiej, zatytułowanego Wytracony z milczenia, zamieszczonego w numerze „Gazety Wyborczej” z 10-12 kwietnia 2004 roku, znajduje się następujący fragment.

„Jesienią 2003 roku Radio Maryja nadawało audycję o uprawianiu filozofii we współczesnym świecie. Zadzwonił ksiądz Jacek Bazarnik, kapelan Centrum Zdrowia Dziecka w Międzylesiu. Powiedział na antenie, że wobec umierającego Kotarbińskiego spełnił 
posługę jako kapłan. Był kapelanem w Instytucie Kardiologii w Aninie. Stanął u łóżka profesora w przeddzień jego śmierci. Rozpoznał uczonego. Jako kleryk widywał go na Krakowskim Przedmieściu. Zetknął się z jego filozofią w seminarium, był nią zafascynowany. Tamtego dnia zacytował kilka zdań o miłości i przyjaźni z książki Kotarbińskiego Medytacje o życiu godziwym. Profesor był poruszony, ściskał księdza za ręce.

$\mathrm{Z}$ oświadczenia księdza Bazarnika napisanego 3 grudnia 2003 roku dla Adama Szpaderskiego i dla redakcji Powszechnej Encyklopedii Filozofii: «Ponieważ miałem pewność, że jest ochrzczony (...) zaproponowałem mu warunkowe rozgrzeszenie i Sakrament Chorych. Wyciagnął do mnie swe dłonie i ja namaściłem je Olejem Chorych, udzielając Błogosławieństwa Papieskiego z Odpustem Zupełnym».

...Mówi ksiądz Jacek Bazarnik: - Nie powinienem był tych faktów ujawniać, bo to jest wydarzenie z kategorii tajemnicy spowiedzi oraz... żeby nie było takiego przekonania, że Kościół chce zawłaszczyć Kotarbińskiego. Wówczas nie opowiedziałem o tym nawet jego rodzinie. Nie możemy mieć gwarancji jego nawrócenia, stan profesora był bardzo ciężki, jego świadomość mogła być zmącona. Ale ja wtedy nie brałem tego pod uwagę. Spełniłem tę posługę, żeby mieć czyste sumienie wobec Boga. Uważam, że dopisane zdanie o «pojednaniu z Bogiem» jest nadużyciem. Nie chciałbym, żeby ono się ukazało w biogramie Kotarbińskiego".

2. Z kolei komentarz do odredakcyjnej noty w PEF przedstawił ks. prof. Andrzej Maryniarczyk SDB, naczelny redaktor tej encyklopedii, a zarazem wiceprezes Polskiego Towarzystwa Tomasza z Akwinu, w wywiadzie udzielonym gazecie „Nasz Dziennik” (nr 242 z 14 października 2004 roku). Po dywagacjach na temat zła, jakiego dopuszczali się ci uczeni, dla których marksizm w latach PRL był ważną inspiracją ich pracy naukowej, ksiądz profesor stwierdził:

„Podobnie, choć tu sprawa jest już trochę inna, pojawiają się problemy z tzw. idolami minionego systemu. Zauważa się strach przed ich swoistym «odbrązowieniem». Taki przypadek pojawił się przykładowo przy biogramie prof. Tadeusza Kotarbińskiego, a dotyczył faktu, że przyjął on pod koniec życia sakrament namaszczenia chorych. Wzbudzało to opór podczas redakcji pierwszej wersji tego hasła przed odnotowaniem tego faktu w biogramie. Fakt ten bowiem naruszał utworzony przez marksizm obraz wzorowego «wolnomyśliciela»".

Do tych wszystkich dokumentów i enuncjacji nawiązuje list dr hab. Adama KOTARBIŃSKIEGO skierowany do naszej redakcji. Oto jego treść:

Warszawa, 18 listopada $2004 \mathrm{r}$.

Szanowny Panie Redaktorze,

W ostatnich miesiącach dotarły do mnie różne co do wagi i formy teksty dotyczące mojego Ojca - Tadeusza Kotarbińskiego. W związku z tymi tekstami pozwalam sobie zwrócić się do Pana Redaktora niniejszym listem, ponieważ uważam, że należy reagować na doniesienia ortodoksyjnych ośrodków wyznaniowych dotyczące zachowania się Tadeusza Kotarbińskiego na krótko przed Jego zgonem, a to dlatego, żeby zapobiec ponawianym próbom rozpowszechniania poglądu, że On «nawrócił się» na łożu śmierci.

Zapis sprawozdawczy księdza, który w ramach swych obowiązków duszpasterskich miał w klinice styczność z mym Ojcem, oceniam jako uczciwy. Teraz chciałbym dodać informację charakteryzującą stan Ojca w okresie Jego pobytu w lecznicy na Hożej. Ojciec był wtedy w stanie uniemożliwiającym $\mathrm{Mu}$ własne czytanie, wiec różne osoby czytały $\mathrm{Mu}$ 
to, na co miał ochotę. Pewnego dnia ja byłem lektorem, jak to się zdarzało podczas moich dyżurów u chorego. W pewnej chwili Ojciec poczuł się zmęczony słuchaniem i nastapiła przerwa w lekturze, ale nadal siedziałem przy Jego łóżku, gotów do wznowienia lektury. I wtedy usłyszałem, jak Ojciec mówi sam do siebie to, co zapamiętałem trwale i dość dokładnie: «Wanda miała dwóch synów... Jeden zmarł za młodu, a co się stało z drugim?...» - A ten drugi to przecież ja, właśnie siedzący obok Niego, przy łóżku, często Go odwiedzający w klinice. Już wtedy występowały u Ojca zaburzenia pamięci i wątków myślowych, które całkiem wygasły w ciagu ostatnich dni przed zgonem, w życiu już bez przytomności.

Wspominam o tym dlatego, że do poglądów Tadeusza Kotarbińskiego nie wolno wprowadzać dodawać tendencyjnych prostackich interpretacji zniekształcających charakter sublimacji intelektualnych i etycznych Jego myśli. Wyciągnięcie ręki Tadeusza Kotarbińskiego na przedśmiertne spotkanie $\mathrm{z}$ wyciągniętą ręką księdza można i należy traktować jako znak szacunku człowieka dla człowieka za jego szlachetne intencje i działania, a nie za całokształt poglądów i postaw.

Na zakończenie tych swoich uwag dodam - niby po arabsku - że psy szczekają, a karawana idzie dalej. To znaczy, że gdybym uznał za stosowne reagować na wszelkie zniekształcenia myśli Ojca, ubierane w pozory duchowej sublimacji - to bym niechybnie musiał popaść w obłęd. To mi całkiem nie odpowiada.

Nie będę miał nic przeciwko temu, jeżeli zachce Pan, Panie Redaktorze, jakoś używać tego listu w dyskusjach nad rolą Tadeusza Kotarbińskiego w kulturze.

$\mathrm{Z}$ wyrazami sympatii.

(-) Adam Kotarbiński

Z odpowiedzi redaktora naczelnego wnoszę, co już zresztą zaznaczyłem, iż komentowana nota do hasła o Kotarbińskim miała być pozostawiona w Encyklopedii w tym samym kształcie, który miała w PEF. To jednak znaczy, że zacytowane komentarze, w tym także stanowisko ks. Bazarnika, zostały przez redaktorów całkowicie zignorowane. Traktuję to jako mocne świadectwo ideologicznego charakteru Encyklopedii.

Adam Szpaderski wycofał swoje hasło. Okoliczności nie znam, ale przypuszczam, że nie zgodził się na umieszczenie informacji o nawróceniu Kotarbińskiego w swoim haśle lub nawet pod nim, a redakcja nie przystała na to. Nowym autorem, jak już zaznaczyłem, został W. Gasparski. Też nie znam szczegółów sprawy, nawet nie pytałem go o nie, uważając takie pytanie za krępujące. Ze struktury hasła wyraźnie wynika, że nie zgodził się na to, by treść noty znalazła się w jego tekście, ale być może została dodana bez jego wiedzy. Wszelako mam w tej sprawie coś do dopowiedzenia. Gdy poproszono mnie o napisanie hasła o szkole lwowsko-warszawskiej, otrzymałem list, w którym przedstawiono mi tryb pracy nad hasłami. Miałem je napisać, przesłać do redakcji, czekać na akceptację i podpisanie umowy, a dopiero potem miało być wypłacone honorarium. Odpisałem, że te warunki mi nie odpowiadaja, nie dlatego, że uważam swoje teksty za niepodlegające krytyce, ale z uwagi 
na to, że przywykłem do innego traktowania autorów, mianowicie przysyłania umowy równocześnie z zamówieniem artykułu, natomiast forma proponowana przez redakcję jest wręcz obraźliwa. Jeśli rzecz dotyczy pieniędzy, zadeklarowałem rezygnację z honorarium, o ile hasło nie zostanie przyjęte. A. Maryniarczyk, bo z nim korespondowałem, przeprosił mnie, wyjaśnił, że przesłane mi warunki są dyktowane względami prakseologicznymi i uznał, że będzie tak, jak sobie życzę. I tak też było we wszystkich trzech przypadkach. Hasła zostały przyjęte bez jakichkolwiek poprawek. W związku z przygotowywaniem Suplementu Maryniarczyk zwrócił się do mnie o napisanie tekstu o jakimś filozofie amerykańskim - nazwiska już nie pamiętam. I znowu pojawiła się pierwotna kolejność, najpierw tekst, potem umowa itd. Tym razem odmówiłem z powodu niewielkiej znajomości twórczości owego filozofa, a przy okazji poruszyłem sprawę hasła o Kotarbińskim. Napisałem wprost, iż moim zdaniem, przyjęty sposób postępowania $\mathrm{z}$ autorami ma na celu kontrolę typu cenzorskiego nad artykułami. Maryniarczyk odpisał, że w takim razie nie mamy o czym rozmawiać i sprawa została zamknięta. Potem poproszono mnie o zgodę na przedruk moich haseł w Encyklopedii, której udzieliłem. Nie mam danych dotyczących zakresu ingerencji redakcji w treść tekstów z wyjątkiem jeszcze jednej osoby (nazwisko pomijam). Kazus hasła o Kotarbińskim i opisana procedura akceptacji haseł nie dyktują nadmiernego zaufania do praktyki redakcyjnej przy obu encyklopediach, a zwłaszcza do jej efektów. Dotyczy to przede wszystkim Encyklopedii, z uwagi na znacznie mniejszy zakres od tego, który obejmuje PEF.

Przechodzę do uzasadnienia tezy, że Encyklopedia jest stronnicza wobec rzeczywistego kształtu współczesnej filozofii polskiej. Hasło „Polska filozofia” (t. 2, s. 380-393; autor: A.B. Stępień - część dotycząca XX w.) wymienia (jeśli dobrze policzyłem) 231 filozofów, w tym 130 chrześcijańskich (60 związanych z KUL). Jeśli chodzi o czasy ostatnie (po 1945 r.), dysproporcja jest jeszcze większa, ponieważ Stępień wymienia 78 filozofów, w tym 54 chrześcijańskich. Hasło „Lubelska szkoła filozoficzna” (t. 1, s. 894-912; autor: A. Maryniarczyk) jest, jak łatwo sprawdzić, obszerniejsze niż poświęcone całej filozofii polskiej, a zajmuje ponad dwa razy więcej miejsca niż dotyczące szkoły lwowsko-warszawskiej (otrzymałem limit stron na to drugie). Notabene, lubelska szkoła filozoficzna (stosowane, a w gruncie rzeczy samo-stosowane, są również takie określniki, jak „lubelska szkoła filozofii klasycznej”, „lubelska szkoła filozofii chrześcijańskiej” i „polska szkoła filozofii klasycznej” - ta ostatnia jest nad wyraz bezpretensjonalna, jak łatwo zauważyć) jest szerzej omówiona w PEF niż Koło Wiedeńskie i filozofia analityczna razem wzięte. Jest to wyraziste świadectwo swoistego pojmowania obiektywności historycznej przez historyków ze szkoły lubelskiej. Gdy zajrzymy do hasła „Fenomenologia polska” (t. 1, s. 369-378; autor: P. Duchliński), wpływowi Ingardena oraz ośrodkom lwowskiemu i krakowskiemu zostały poświęcone 2 strony, a lubelskiemu 
3 strony. Nawiasem mówiąc, dobrze pamiętam z czasów studiów, że Ingarden nie był zbytnio zachwycony podkreślaniem podobieństw pomiędzy jego ontologią a metafizyką tomistyczna, co czyniono w Lublinie, aczkolwiek nie miał nic przeciwko komentowaniu swoich poglądów przez przedstawicieli jakiejkolwiek orientacji filozoficznej. Znajdujemy też taką ocenę (t. 2, s. 392):

Zauważa się natomiast pewne braki w znajomości dziejów filozofii, w różnym też stopniu uwzględniany jest dorobek tradycji. Pod względem kultury historyczno-filozoficznej może korzystnie prezentują się autorzy związani z lubelską szkołą filozoficzną.

Pierwsze zdanie nie jest zbyt transparentne, gdyż jego autor (A.B. Stępień) nie pokusił się o jakąkolwiek ilustrację swojej oceny. Ogólny tenor Encyklopedii może sugerować, że niedomagania w znajomości historii filozofii i uwzględnianiu tradycji dotyczą tego, co w szkole lubelskiej uchodzi za klasykę. Rozżalenie Stępnia jest całkowicie zrozumiałe, skoro sam ma inny pogląd na to, co najważniejsze w filozofii polskiej. Niemniej jednak wypadałoby nie mierzyć wszystkiego własną linijką. Jeżeli zaś rzeczone braki dotyczą czegoś innego, tj. „pozalubelskiego”, winny być wyraźnie wskazane.

Na początku Encyklopedii (t. 1, s. 13) znajduje się uniwersalizująca diagnoza:

W ukazywaniu dziejów polskiej kultury, w tym także nauki, możemy niekiedy spotkać się z próbą budowania w świadomości społecznej mitu o braku polskiej filozofii. Prowadzone prace encyklopedyczne pozwalają stwierdzić, że polska kultura ma prawo szczycić się wieloma wybitnymi przedstawicielami nauki, sztuki, literatury, polityki, a także filozofii.

Analizując przygotowywany materiał do „Encyklopedii filozofii polskiej”, a wcześniej do „Powszechnej Encyklopedii Filozofii”, można zauważyć w dziejach filozofii polskiej kilka dominujących dziedzin badań, w których Polacy wnieśli znaczący wkład do światowego skarbca filozofii i kultury.

Słowo „niekiedy” jest bardzo wygodne, gdyż zaznacza, że coś działo (dzieje) się, aczkolwiek nie informuje o częstości czy też zasięgu owego czegoś. Wszelako budowanie jest zawsze jakimś procesem rozciągającym się w czasie i przestrzeni, czyli gdzieś i kiedyś, a dotyczy to w szczególności budowania mitów w świadomości społecznej. Dowiadujemy się więc z powyższego oświadczenia, że niekiedy, gdzieś i kiedyś, ktoś budował w społecznej świadomości mit o braku filozofii polskiej, ale nie wiemy, kto, gdzie i kiedy.

A oto wykaz ,dominujących dziedzin badań, w których Polacy wnieśli znaczący wkład do światowego skarbca filozofii i kultury" (t. 1, s. 13). Oto on (w nawiasach nazwiska filozofów wskazanych jako ważni w danych dyscyplinach filozoficznych): filozofia przyrody (Witelo, Benedykt Hesse, K. Kłósak), filozofia polityki i etyka (Paweł Włodkowic, J. Woroniecki, T. Kotarbiński, 
J. Kalinowski, K. Wojtyła, T. Ślipko), filozofia historii i kultury, historia filozofii (J.-M. Hoene-Wroński, A. Krokiewicz, W. Tatarkiewicz, S. Swieżawski), logika i metodologia (Michał z Wrocławia, Mikołaj z Mościsk, K. Twardowski, J. Łukasiewicz, K. Ajdukiewicz, A. Tarski, S. Kamiński), fenomenologia (R. Ingarden) i metafizyka z antropologią (M.A. Krappiec, K. Wojtyła). Redaktorzy wybrali 22 nazwiska (jedno dwukrotnie) z całej historii filozofii polskiej, w tym 8 ze szkoły lubelskiej, a biorąc pod uwagę współczesność, lublinianie z KUL stanowią więcej niż połowę ( 8 na 15$)$. W konsekwencji nie dziwią konkluzje Maryniarczyka (t. 1, s. 13, 15):

Jeśli pierwsze cztery [tj. tradycje przyrodniczo-kosmologiczna, polityczno-etyczna, logiczno-metodologiczna, fenomenologiczna - J.W.] miały swoje historyczne ugruntowanie, tzn. przewijały się przez całe dzieje, to na szczególną uwagę zasługuje ostatnia, metafizycznoantropologiczna.

Wśród historyków myśli utarł się bowiem pogląd, że w dziejach polskiej filozofii nie występuje tradycja metafizyczno-antropologiczna. Okazuje się jednak, że we współczesnej polskiej filozofii wyróżnia się silny nurt metafizyczno-antropologiczny. Został on zapoczątkowany i ugruntowany wraz z powstaniem w latach 50. XX w. lubelskiej szkoły filozoficznej. Dzięki tej szkole, w ramach filozofii polskiej doszło do sformułowania współczesnej koncepcji metafizyki realistycznej, co jest ewenementem w filozofii światowej. Została także wypracowana uniwersalna teoria człowieka jako osoby, która może stanowić podstawę nauk o człowieku i ludzkim działaniu (etyki, pedagogiki, filozofii kultury, prawa, religii, polityki itd.).

Fakty te pozwalają przezwyciężyć powstałe w ciągu wieków mity, że Polacy nie mają własnych, znaczących tradycji filozoficznych, a wszystko, co posiadają, jest tylko recepcją cudzych myśli. „Encyklopedia filozofii polskiej” w sposób przekonywujący pokazuje, że „Polacy nie gęsi, iż swój język mają” nie tylko w dziedzinie literatury, ale również i w zakresie filozofii. [...]. Inicjatywa opracowania i wydania „Encyklopedii filozofii polskiej” [...] zrodziła się [...] w trakcie finalizowania prac nad „Powszechną encyklopedią filozofii”, gdy uświadomiono sobie, jak wielki wkład wnosili i wnoszą Polacy w polską i światową kulturę filozoficzną.

Koniec zacytowanego fragmentu jest osobliwy. Po pierwsze dlatego, że wygląda na to, że nie uświadomiono sobie wielkiego wkładu Polaków do światowej kultury filozoficznej przed finalizowaniem prac nad PEF, a po drugie, że polska kultura filozoficzna nie stanowi części światowej. To pewnie zwyczajny lapsus językowy, podobnie jak wielce oryginalne stwierdzenie, że Polacy wnieśli wielki wkład w polską kulturę filozoficzną. W samej rzeczy jest ono niezwykle odkrywcze, ponieważ rzeczony wkład mógł zostać uskuteczniony np. przez Eskimosów lub Pakistańczyków.

Przechodząc do szczegółów, Ingarden byłby z pewnością zachwycony, gdyby dowiedział się, że tradycja fenomenologiczna przewijała się przez całe dzieje filozofii polskiej, tj. od Kadłubka i Witelona. Być może zdecydowałby 
się na wykazanie, że w Optyce tego pierwszego, a nie w dziełach Husserla, obecna jest fenomenologiczna teoria barwy (to oczywiście żart, bazujący na dwuznaczności terminu „fenomenologia”). To, że współczesna koncepcja metafizyki realistycznej została sformułowana w ramach filozofii polskiej, jest równie prawdziwe, jak to, że Lublin znajduje się Polsce, a Watykan na Półwyspie Apenińskim. Rzeczona koncepcja bez wątpienia powstała w obrębie filozofii polskiej (nie dyskutuję kwestii, czy nie powstałą też gdzie indziej, np. w dziełach Gilsona), a nie np. afrykańskiej, japońskiej czy chińskiej. Widać jednak wyraźnie, że Maryniarczyk operuje (w obu zacytowanych ustępach) terminem „filozofia polska” w sposób dwuznaczny. Po pierwsze i z czysto semiotycznego punktu widzenia, termin ten posiada sens opisowy i odnosi się do ogółu wytworów sprawionych przez filozofów polskich, a z drugiej strony oznacza filozofię mającą jakieś cechy swoiste, polskie właśnie. Nazwa „polska filozofia narodowa" ma takie konotacje, gdy, a tak jest w większości prac historyczno-filozoficznych, wskazuje na pewien rozdział w dziejach myśli. Po drugie czy też nawet trzecie, mówi się o filozofii polskiej jako o czymś cennym, wyrażającym polskość. W znanym sporze o polską filozofię narodową miano na uwadze takie właśnie znaczenie, wyraźnie wartościujące, dla jednych pozytywne, a dla innych negatywne. Przypuszczam, że mit (teraz ,powstały w ciaggu wieków”, a nie funkcjonujący ,niekiedy”) o braku filozofii polskiej, o którym była mowa wcześniej, dotyczy filozofii polskiej w tym drugim, wartościującym znaczeniu. W rezultacie, nie bardzo wiadomo, kiedy Encyklopedia filozofii polskiej zajmuje się filozofią polską w sensie opisowym, a kiedy - wartościującym. Użycie terminu „tradycja” przez Maryniarczyka też jest niejednoznaczne. Powiada, że zdaniem historyków myśli, „w dziejach polskiej filozofii nie występuje tradycja metafizyczno-antropologiczna”. Następne zdanie zaczyna się od zwrotu „Okazuje się jednak”, a więc kontrastującego coś z czymś, w tym wypadku nurt metafizyczno-antropologiczny z czymś innym.

Wieloznaczności wskazane wyżej utrudniają zrozumienie sformułowań użytych przez Maryniarczyka, zwłaszcza w kwestii tego, co jest drugim członem kontrastu zaznaczonego przez „Okazuje się jednak”. Po pierwsze, zacytowany tekst można rozumieć tak, że historycy filozofii coś prawdziwie skonstatowali - to mianowicie, że w dziejach naszej filozofii nie było tradycji metafizyczno-antropologicznej, a wtedy powstanie stosownego nurtu jest przeciwstawione jego brakowi w rodzimym dorobku myślowym. Po drugie, nie jest też wykluczone, że dziejopisowie pomylili się (przypominam o pewnych brakach $\mathrm{w}$ znajomości historii filozofii, aczkolwiek naprawianych, jakżeby inaczej, przez szkołę lubelską), co znaczy, iż polska szkoła filozofii klasycznej nawiązała do zastanej tradycji. Ostatni akapit wprowadza jeszcze jedna modyfikację, bo opowiada o posiadaniu przez Polaków tradycji stosunkowo 
krótkiej, bo obecnej od jakichś 60 lat. Tak więc nurt metafizyczno-antropologiczny jest albo kontynuacją starej tradycji, albo tradycją nową. Dowiadujemy się natomiast, że jest silny, znaczący i wyróżnia się, a nawet (jako współczesna koncepcja metafizyki realistycznej) jest ewenementem światowym. Dobrze byłoby, gdyby jakiś obserwator zewnętrzny i o znaczeniu międzynarodowym potwierdził te oceny. Gdy spotkałem po raz pierwszy o. J.M. Bocheńskiego w 1986 r. natychmiast zapytał mnie, co tam nowego „u o. Krapca, mojego współbrata". Odpowiedziałem, że, o ile wiem, nadal zajmuje się teorią bytu. Bocheński oczywiście wiedział, a zadał to pytanie chyba tylko po to, aby wygłosić swój komentarz (dobrze znany także w Lublinie, jak potem się dowiedziałem): „Ja to nazywam teorią od-bytu” (sposób akcentowania wyraźnie wskazywał, że nie należy ostatniego słowa rozumieć jako frazy „od bytu”). Tego rodzaju dosadne sformułowanie uważam za niestosowne, ale, z drugiej strony, samochwalcy z lubelskiej szkoły filozoficznej winni nieco samoograniczyć się w peanach na własny temat, ponieważ są one połączeniem groteski z pretensjonalnością, fuzji nader widocznej w ocenie ks. prof. A. Maryniarczyka, że o. Krapiec uczynił z Tomaszem z Akwinu to, co ten ostatni z Arystotelesem (cytuję z pamięci). Gdy opowiedziałem o tym stwierdzeniu jednemu ze znajomych księży, ironicznie zauważył, że być może chodzi o to, że założyciel polskiej formacji filozofii klasycznej ochrzcił Akwinatę.

Powracam do wkładu Polaków do ,światowego skarbca filozofii”. I tutaj notujemy dwuznaczność. Po pierwsze, może chodzić o tych, których dorobek został uznany za znaczący w skali międzynarodowej, lub też takich, których nie doceniono, chociaż na to zasłużyli. Pomijam ocenę filozofów dawniejszych (Witelo, Benedykt Hesse, Michał z Wrocławia, Mikołaj z Mościsk czy Hoene-Wroński) jako postaci światowego formatu; Ajdukiewicz, Ingarden, Kalinowski, Kotarbiński (ale nie jako etyk, tylko jako twórca reizmu), Łukasiewicz, Tarski, Tatarkiewicz, Twardowski (ale nie jako logik czy metodolog) zyskali międzynarodowe uznanie. Wojtyła stał się popularny i ceniony (w świecie) jako filozof dopiero po jego wyborze na papieża. Krokiewicz i Swieżawski na pewno zasługują na większą międzynarodową renomę, niż im przypadła w udziale, ale taki już jest los filozofów (i przedstawicieli innych dyscyplin naukowych, głównie humanistów), gdy ich dzieła nie są dostępne w jakimś języku spełniającym rolę lingua franca. Natomiast uważanie Kamińskiego, Kłósaka, Krąpca, Woronieckiego czy Ślipki za filozofów o znaczeniu międzynarodowym, nawet niewielkim, jest zwyczajnym nieporozumieniem, a jeśli się mylę, proszę o jakąś dokumentację, ale spoza Lublina. Nie znaczy to, że odmawiam wartości ich dokonaniom, ale, co do ich znaczenia, nie przekroczyli skali lokalnej. Zdumiewa natomiast pominięcie oczywistych przykładów „wkładu do światowego dziedzictwa filozoficznego", jak np. o. Józef M. Bocheński (historia logiki), Ludwik Fleck (filozofia nauki), Stanisław Leśniewski (logi- 
ka), Bronisław Malinowski (etnologia i antropologia kultury), Leon Petrażycki (teoria prawa) czy Florian Znaniecki (socjologia). Chociaż wszyscy oni maja swoje osobne hasła, Maryniarczyk o nich zapomniał w preambule do Encyklopedii. Przypadek, zwyczajne niedbalstwo, czy chęć ułożenia proporcji w dystrybucji osiagnięć na korzyść szkoły lubelskiej?

Mieczysław A. Krapiec jest postacią szczególnie uhonorowaną. Hasło o nim liczy sobie 5,5 strony. Główny twórca szkoły lubelskiej ustępuje pod tym względem tylko Ajdukiewiczowi (6,5 strony) i Wojtyle (7 stron). Inni znaczący polscy filozofowie współcześni zagospodarowali takie oto areały: Ingarden -4 strony, Kotarbiński -4 strony, Łukasiewicz -4 strony, i Twardowski -4 strony. Krapiec bije wszystkich na głowę hasłami rzeczowymi: analogia transcendentalna Krapca, filozofia prawa w ujęciu Krąpca, kultury filozofia w ujęciu Krąpca, metafizyka człowieka w ujęciu Krapca, metafizyka realistyczna w ujęciu Krappca, personalizm metafizyczny Krąpca, polityki filozofia Krąpca, sąd egzystencjalny w ujęciu Krąpca i separacja metafizyczna w ujęciu Krapca. Pozostałe rzeczowe hasła powiązane z osobami są następujące: antyindukcjonizm Łukasiewicza, dedukcja naturalna Jaśkowskiego, dyrektywalna koncepcja znaczenia (Ajdukiewicz), etyka niezależna Kotarbińskiego, kauzalna teoria czasu Mehlberga, Kołakowskiego krytyka marksizmu, logika dyskusyjna Jaśkowskiego, logika indukcji Lindenbaumowej, logika kierunkowa Rogowskiego, logika kwantowa Zawirskiego, logika modalna Łukasiewicza, logika niefregowska Suszki, logika norm Kalinowskiego, logika temporalna Łosia, mereologia Leśniewskiego, nauki teoria Kamińskiego, ontologia Leśniewskiego, personalizm etyczny Wojtyły, personalizm uniwersalistyczny Bartnika, prototetyka Leśniewskiego, radykalny konwencjonalizm Ajdukiewicza, religii filozofia w ujęciu Zdybickiej, solidarność społeczna w ujęciu Jana Pawła II, semantyczna teoria prawdy Tarskiego, twierdzenie Lindenbauma o maksymalizacji, twierdzenie Lindenbauma o matrycach i twierdzenie Tarskiego. Takich haseł jest 36, w tym 15 związanych ze szkołą lubelską. Gdy jednak odejmiemy logikę (formalną i filozoficzna), pozostaje 20 hasel, w tym 14 przypada na „krewnych i znajomych” redaktora naczelnego i głównego konsultanta merytorycznego. Encyklopedia ma też ogólniejsze hasła rzeczowe, mianowicie: czasopisma filozoficzne w Polsce, Koło krakowskie, Komisja Edukacji Narodowej, logika polska, Lubrańskiego Akademia, lwowsko-warszawska szkoła, marksistowski materializm, marksizm polski w dialogu, mediewistyka polska, mesjanizm, naród polski, neotomizm polski, notacja polska, polska filozofia, polska szkoła prawa narodów, poznańska szkoła metodologiczna, towarzystwa i instytucje filozoficzne w Polsce oraz zjazdy filozoficzne w Polsce; w sumie jest ich 18, w tym 3 na tematy dawniejsze. Tak więc Encyklopedia zawiera ogółem 35 haseł rzeczowych (pomijając logikę w sensie ścisłym) dotyczących współczesności. Blisko połowa z nich (16; nawet 17, ponieważ 
hasło o narodzie uwzględnia tylko poglądy głoszone przez neoscholastyków, przede wszystkim lubelskich) jest poświęcona neotomizmowi, a 14 - szkole lubelskiej. Tak więc Encyklopedia spełnia w sposób bardzo szczególny zasadę toutes proportions gardées. Zastosowana arytmetyka nie ma oczywiście ostatecznej siły dowodowej, ale pozwala na postawienie i uzasadnienie hipotezy, że, wedle Encyklopedii, są równi i równiejsi lub też ważni i ważniejsi, a nawet najważniejsi. Uzupełniając wcześniejsze uwagi, wskażę jeszcze kilka wyraźnych braków w zestawie haseł rzeczowych, związanych z osobami (i tutaj racją jest porównanie z tymi, które zostały uwzględnione; wykaz jest zapewne niepełny): absolutyzm i relatywizm w teorii prawdy (Twardowski), determinizm (Łukasiewicz), czynności i wytwory (Twardowski), dzieło literackie (Ingarden), gramatyka kategorialna (Ajdukiewicz), historia logiki w Polsce (Łukasiewicz, Bocheński i inni), interpretacje logiki dawnej (Łukasiewicz i inni), krytyka psychologizmu (Łukasiewicz, Ingarden), logika intensjonalna (Łoś), metodologia pragmatyczna (Ajdukiewicz), ontologia formalna (Ingarden), psychologia deskrypcyjna (Twardowski, Czeżowski), reizm (Kotarbiński), teoria modeli (Tarski) czy twierdzenie o dedukcji (Tarski), a przynajmniej kilka $\mathrm{z}$ tych tematów przedstawia światowe osiągnięcia filozofów polskich. Brakuje też ogólnych haseł o poszczególnych dyscyplinach filozoficznych, np. filozofii języka, filozofii nauki, etyce czy estetyce, w których Polacy też sporo osiągnęli. Być może te opuszczenia biorą się ze słusznego skądinąd przeświadczenia, że dokonania szkoły lubelskiej wypadają dość blado w szerszym planie porównawczym, a jeśli tak jest, to redaktorzy Encyklopedii wykazali niezłą orientację historyczną w tym przypadku. Mamy za to w miarę obszerne hasło o mediewistyce polskiej (t. 2), pewnie dlatego, że można w nim było wiele dobrego (i słusznie) powiedzieć o rezultatach uzyskanych przez historyków z obozu neoscholastycznego.

Encyklopedia poświęca bardzo wiele uwagi ogólnej sytuacji politycznej i społecznej w Polsce po 1945 r., kontynuując w tej mierze styl już przyjęty w PEF. Nie ma żadnego powodu, aby pomijać ten wątek, ponieważ ogólny kontekst polityczny i społeczny był pod wieloma względami decydujący dla sytuacji filozofii polskiej w tym okresie. W PEF (t. 1, s. 9; oznaczone jako (a)) i Encyklopedii (t. 1, s. 10-11; oznaczone jako (b)) czytamy (w obu wypadkach są to wstępy do całości):

(a) Wybuch drugiej wojny światowej, okupacja Polski, niszczenie polskiej inteligencji i, w konsekwencji, polskiej nauki, spowodowały załamanie podstaw kultury. Towarzyszyło temu zaprogramowane prześladowanie Kościoła katolickiego, czego wyrazem były proporcjonalnie najwyższe straty osobowe wśród duchowieństwa powstałe pod okupacją niemiecka, jak i sowiecką. Wprowadzenie ideologii komunistycznej, wrogiej dziedzictwu wielowiekowej tradycji, było kolejną przyczyną dewastacji polskiej kultury. Ideologia ta, w postaci marksistowskiej filozofii, stała się obowiązkowa na wszystkich szczeblach 
nauczania szkolnego, a także w propagandzie szerzonej w środkach przekazu oraz w książkach i czasopismach.

Trwające pół wieku niewolenie wolnej myśli spowodowało w narodzie znaczną utratę świadomości własnej kultury i doprowadziło do deformacji światopoglądowych. Skutki te nie ustąpiły wraz z odzyskaniem w roku 1989 niezawisłości, ponadto propaganda laicko-ateistyczna nasiliła swe oddziaływanie na umysły Polaków, a przygotowany, dostosowany do panującej wokół mody kulturowej program szkolnego nauczania i formacji nie daje gwarancji przeciwstawiania się nowemu zniewoleniu. W tej sytuacji należało dostarczyć kształcącej się młodzieży skutecznej pomocy w postaci niezafałszowanej ideologicznie filozofii, która zawsze stoi u podstaw rozumienia kultury i rzetelnego myślenia.

(b) W dziejach polskiej filozofii, które rozpoczynają się w XIII w., można dostrzec pewną ciagłość. Wyjątek stanowi XX-wieczny okres komunizmu, kiedy to polskim ośrodkom naukowym marksizm został narzucony środkami administracyjnymi. Wskutek tego doszło do podwójnego zniekształcenia filozofii. Po pierwsze, uczyniono z niej narzędzie ideologicznej walki partii komunistycznej i w ten sposób poddano degradacji oraz instrumentalizacji. Po drugie, podmieniono cel filozofii. Zamiast służyć poznaniu świata i człowieka, filozofia stała się ideologią - zajęła się przekształcaniem tego świata, a przede wszystkim przemianą człowieka i społeczeństwa. Zaczęła pełnić funkcję narzędzia inżynierii społecznej. Z tej racji „Encyklopedia filozofii polskiej” przyczynia się do odbudowy ethosu filozoficznego poznania i ethosu samego filozofa. [...] Nie bez znaczenia przy podejmowaniu inicjatywy opracowania „Encyklopedii filozofii polskiej” była świadomość sytuacji kulturowej, w której znalazła się Polska po tzw. transformacji ustrojowej. Rugowanie filozofii z kształcenia uniwersyteckiego z uwagi na kult techniki i kształcenia techniczno-pragmatycznego stanowi realne zagrożenie kształcenia humanistycznego, bez którego nie ma prawdziwego wykształcenia. Pragniemy przez tę encyklopedię ukazać piękno i szlachetność oraz celowość edukacji filozoficznej, która w tradycji polskiego szkolnictwa była podstawą także kształcenia przyrodniczego i techniczno-matematycznego.

Oba fragmenty formułują nie tylko diagnozę, ale i środki przeciwdziałania skutkom wcześniejszej katastrofy kulturowej, w szczególności filozoficznej, a także negatywnym następstwom transformacji ustrojowej.

Przechodząc do analizy (a) i (b), rozpocznę od uwagi, że literalne odczytanie (b) prowadzi do zgoła nieoczekiwanego wniosku, że marksizm został narzucony wszystkim, a w tym również szkole lubelskiej. To jednak tylko żart, wypływający ze skrótu myślowego, jaki Maryniarczyk (to on podpisał „Słowo wprowadzenia”) zastosował do wyłożenia swojego poglądu na stan filozofii polskiej po 1945 r. Być może ani on, ani Krąpiec (obaj podpisali preambułę do PEF) nie spostrzegli, jak łatwo przerobić ich słowa na zupełnie inne sformułowanie, na pewno niezamierzone przez obu autorów. Podstawmy w (a) „partii komunistycznej” za „Kościoła katolickiego” oraz „komunistów” za „duchowieństwa”. Tak spreparowany pierwszy akapit mógłby być umieszczony w programowym tekście dotyczącym nauczania filozofii w PRL około 1951 r. lub 1968 r., gdy powiadano o zgubnych skutkach ulegania burżuazyjnym modom i zbawczych skutkach dostarczenia młodzieży podręczni- 
ków i encyklopedii w nowym duchu. Bez kłopotu można dostosować resztę tekstu (a) i (b) do nowej wersji. W samej rzeczy, burżuazyjna reakcja zawsze dokonywała podwójnego zafałszowania filozofii. Po pierwsze, uczyniła z niej narzędzie walki ideologicznej imperialistów z ruchem komunistycznym i w ten sposób poddano ją (filozofię) degradacji i instrumentalizacji. Po drugie, podmieniła cel filozofii, która zamiast służyć poznaniu świata i człowieka, stała się ideologią - zajęła się przekształcaniem tego świata, a przede wszystkim stała się przemianą człowieka i społeczeństwa w celu jego zniewolenia. Zaczęła pełnić funkcję narzędzia inżynierii społecznej. $Z$ tej racji „Encyklopedia filozofii marksistowskiej" (bo taką nazwę trzeba by wprowadzić) przyczynia się do odbudowy etosu (nie „ethosu”) filozoficznego poznania i etosu samego filozofa, a także ukazuje szlachetność edukacji filozoficznej, zgodnie z postępowymi tradycjami polskiego szkolnictwa. Kiedyś jeden z kolegów napisał pozytywną recenzję książki dotyczącej metodologii z punktu widzenia marksizmu, a moja ocena tego dzieła była krytyczna. Ów filozof (studiował w KUL - jeszcze przed powstaniem szkoły lubelskiej) dostrzegł podobieństwo recenzowanego dzieła $\mathrm{z}$ neoscholastyka, którą bardzo sobie cenił. $\mathrm{Ba}$, gdy poinformowałem jednego z przedstawicieli szkoły lubelskiej o moich zastrzeżeniach wobec Encyklopedii, odparł, że uprawiam nie krytykę, ale krytykanctwo, a więc posłużył się typową figurą retoryczną używaną przed 1989 r. i to przez tych, którzy go (i jego ideowych pobratymców) zniewalali przez pół wieku. Twórcze wykorzystanie idei głównego przeciwnika w Encyklopedii jest łatwo zauważalne i robi spore wrażenie.

Skutki okupacji były oczywiście takie, jak to ujmuje pierwsze zdanie fragmentu (a), aczkolwiek sformułowanie jest mocno przesadzone, ponieważ odbudowana kultura polska w pierwszych latach powojennych wcale nie świadczyła o tym, że jej podstawy uległy załamaniu. Ale już drugie zdanie budzi wątpliwości, ponieważ odwołanie się do statystyki (tj. proporcjonalnych strat) jest demagogiczne. Straty duchowieństwa wymagają pewnej relatywizacji. W diecezjach włączonych do Rzeszy po 1 września 1939 r. wynosiły (wśród duchownych diecezjalnych, nie dysponuję szacunkami dla zakonów) od około $31 \%$ do prawie $50 \%$, a więc były bardzo duże. W pozostałych, tj. na terenach Generalnego Gubernatorstwa (włącznie z terenami zajętymi przez ZSRR w latach 1939-1941) od około 4\% do około 29\%. Represje wobec księży na terenach włączonych do Rzeszy nie wynikały z jakiegoś wyjątkowo zaprogramowanego prześladowania Kościoła katolickiego, ale z konsekwentnej polityki germanizacyjnej. Ogółem w latach 1939-1945 zginęło 18,1\% księży, natomiast straty całej ludności polskiej wyniosły $16 \%$. Gdy jednak ograniczymy się do Generalnego Gubernatorstwa w granicach z 1941 r., procent ofiar wśród duchownych wyniesie $11 \%$. Nie podaję tych danych, aby w jakikolwiek sposób pomniejszać skutki okupacyjnych represji wobec duchownych. Przypuszczam jednak, że 
informacja o stratach osobowych duchowieństwa jako proporcjonalnie największych (to oczywiście nieprawda, bo Niemcy zabili 90\% polskich Żydów, a np. w Warszawie w czasie powstania w 1944 r. zginęło około 20\% jej cywilnych mieszkańców; wszystko więc zależy od tego, jak ustala się proporcje, czego one dotyczą i jak są porównywane $\mathrm{z}$ innymi) nie została podana bez jakiegoś celu. Można przypuścić, iż jej celem jest ugruntowanie przekonania o szczególnym miejscu Kościoła katolickiego w kulturze polskiej, także z uwagi na jego straty w czasie okupacji. Z rzeczowego punktu widzenia, wtrącenie na temat Kościoła katolickiego, jego prześladowania i strat w czasie II wojny światowej, nie ma żadnego znaczenia dla dyskutowanej kwestii, tj. historii filozofii w Polsce, poruszanej w tak ogólnym planie, jak to ma miejsce w (a).

Krapiec i Maryniarczyk powiadają o kolejnej dewastacji polskiej kultury pod rządami komunistycznymi. Traktują lata 1944/1945-1989 jako jeden okres, niszczący kulturę narodową we wszystkich jej dziedzinach. Nie zamierzam twierdzić, że owe czterdzieści pięć lat było okresem sprzyjającym kulturze. Okoliczności hamujące jej rozwój są dobrze znane i nie ma powodu, aby je tutaj przytaczać po raz kolejny, aczkolwiek to, że Encyklopedia wspomina o nich, nie powinno być przedmiotem jakiegokolwiek zarzutu. Zacytowane fragmenty jednak kompletnie ignorują to, że należy wyróżnić rozmaite podokresy, np. 1944/45-1948/49 (te lata, przynajmniej w życiu filozoficznym, były bardziej podobne do międzywojnia niż czasów późniejszych), 19501956, 1957-1968/70, 1971-1980 i 1981-1989; o ilość podokresów i rozmaite szczegóły można się spierać, np. o to, czy nie był cezurą i rok 1964 (tzw. List $34 \mathrm{w}$ sprawie kultury i jego następstwa). W każdym z tych podokresów inaczej wyglądała reglamentacja kultury, cenzura, kontakty zagraniczne itd., a co za tym idzie, stopień liberalizmu dopuszczany przez władze lub też wymuszany na niej, np. przez okoliczności międzynarodowe lub wewnętrzne działania opozycyjne. To prawda, że intencją władzy była kontrola nad kulturą tak silna, jak to było możliwe czy pożądane w danym momencie, że stosowano rozmaite środki administracyjne w celu doprowadzenia do pełnego zwycięstwa idei komunistycznych, w co zresztą komuniści wierzyli, jeśli nie wszyscy, to przynajmniej niektórzy. Jeśli fragmenty oznaczone jako (a) i (b) miałyby dotyczyć polityki władz, można by się z nimi zgodzić, ewentualnie po pewnych retuszach stylistycznych, np. dotyczących zniewolenia (takie sformułowanie uważam za nieadekwatne, ale przecież nie słów rzecz dotyczy). W szczególności, teza, że liberalizacja polityki kulturalnej, oczywisty fakt $\mathrm{w}$ pewnych latach, była tylko sprytnym manewrem taktycznym, a nie rzeczywistą intencją, na pewno nadaje się do poważnej dyskusji. Mój pogląd jest taki, że władza pod tym względem była nieraz wyraźnie podzielona, ale to nie zmienia oceny, że kultura polska rozwijała się w warunkach dalekich od normalności. 
Wszelako Krąpiec i Maryniarczyk całkowicie ignorują drugą stronę medalu, tj. wytwory kulturowe, które w tym okresie powstawały. Czy polska szkoła filmowa, kino moralnego niepokoju z lat 70., utwory Bacewiczównej, Lutosławskiego i Pendereckiego, powieści Andrzejewskiego, Iwaszkiewicza i Konwickiego, opowiadania Borowskiego, poezja Gałczyńskiego, Słonimskiego, Szymborskiej i Tuwima, spektakle teatralne Dejmka i Swiniarskiego, plastyka Kantora, aby wymienić tylko kilka przykładów, są świadectwem zniewolenia przez komunizm? To prawda, że pisarze, poeci, kompozytorzy i plastycy szli na kompromisy, stosowali autocenzurę czy nie podejmowali tematów drażliwych lub czynili to w sposób niepełny, ale jednak tworzyli i stworzyli dzieła wybitne, które były dostępne ogółowi, czekającemu na takowe i ceniącemu twórców za to, czego dokonali. Nawet jeśli traktować aktywność na polu kultury jako grę środowisk artystycznych z władzą, bardzo często wychodziły one zwycięsko z tych potyczek, nie przez przypadek czy łaskawość decydentów, ale z powodu swego uporu, odwagi i talentu. Pogląd wyrażony w (a) i (b) nie tylko to ignoruje, ale dezawuuje w sposób wyjątkowo niesmaczny. Koniec fragmentu (b) jest w gruncie rzeczy ułożony wedle dobrzej znanej melodii o bardzo groźnym spisku przeciw zdrowym siłom narodu. Uwagi te sugerują, że żartobliwa parafraza przez podstawienie nie jest bezpodstawna. Krapiec i Maryniarczyk sami podstawiają jedną ideologię za inną. W kwestii ich apelu o edukację filozoficzną warto zauważyć, że środowisko filozoficzne stara się od 1989 r. o przywrócenie filozofii w szkołach średnich, ale władze oświatowe są na to głuche. Nie znam znaku poparcia dla tych starań ze strony szkoły lubelskiej. Co więcej, dochodzą głosy o tym, że niektóre kręgi katolickie traktują wprowadzenie filozofii do szkół jako zagrożenie dla nauczania religii. Pojawił się nawet postulat, aby filozofii uczyli katecheci, ponieważ są do tego należycie przygotowani. Być może Maryniarczyk ograniczył się wyłącznie do postulatów wobec kształcenia na poziomie uniwersyteckim właśnie dlatego, że Kościół katolicki nie chce filozofii w szkołach średnich.

Sytuacja filozofii była pod rządami komunistów trudna (dalej korzystam z rozdz. XII wspomnianej Historii filozofii polskiej; por. także J. Woleński, „From Controlled Liberalism to Real Pluralism. The Development of Philosophy in Poland at the End of Communism Era", w: 20 Years After the Collapse of Communism. Expectations, Achievements, and Disillusions of 1989, ed. by N. Hayoz, L. Jasień and D. Koleva, Peter Lang 2011, s. 559-571), ponieważ znajdowała się ona pod specjalnym nadzorem jako dyscyplina ideologiczna. Miało to nader istotne znaczenie dla polityki kadrowej, w tym awansowej, finansowego i organizacyjnego popierania badań oraz nauczania. Te fakty, a także to, że losy filozofii (i innych tzw. dyscyplin ideologicznych) były silnie uzależnione od aktualnej sytuacji politycznej, stanowią znamię wyraźnej patologii w relacji do normalnych standardów akademickich. Niemniej jednak 
trudno się zgodzić z diagnozą Krąpca i Maryniarczyka, tj. że nastapiła katastrofa w polskim życiu filozoficznym. Chociaż marksizm był oficjalnie popierany jako filozofia właściwa i co za tym idzie obowiązująca, a inne kierunki postrzegano i oceniano przez pryzmat ich stosunku do myśli marksistowskiej, zasad tych nigdy nie zrealizowano do końca. W samej rzeczy, nacisk polityczny słabł w miarę upływu czasu (z pewnymi fluktuacjami, np. w 1968 r.). Ważniejsze było to, że filozofia w Polsce nie była jednolita w latach 1945-1989. Było tak m.in. z powodu stosunkowo żywych kontaktów filozofów polskich z kolegami z zagranicy po $1956 \mathrm{r}$. oraz szerokiego dostępu, także prywatnego, do literatury fachowej, którą można było zamawiać indywidualnie bez specjalnych ograniczeń. Wystarczy przeglądnąć „Studia Filozoficzne” i „Ruch Filozoficzny”, aby zobaczyć, jak wiele artykułów niemarksistowskich było w nich obecnych, i jak wiele polemik toczyli marksiści pomiędzy sobą. Michał Hempoliński opowiadał mi o zarzutach, jakie go spotkały w połowie lat 1980. ze strony ortodoksyjnych marksistów, że jako redaktor „Studiów Filozoficznych” nie preferował tekstów marksistowskich. Odpowiedział, że wybiera teksty dobre, niezależnie od tego, z jakiego obozu filozoficznego przychodzą. Został odwołany w 1986 r., ale nie za wspomniane zasady redagowania pisma, ale z powodu ukazania się numeru 8-9/1985, dedykowanego Klemensowi Szaniawskiemu, czołowemu polskiemu opozycjoniście, wydanego mimo ostrzeżenia, że jego publikacja spowoduje konsekwencje personalne, co też się stało. Notabene, nikt ze szkoły lubelskiej nie zdecydował się na napisanie tekstu do tego zeszytu „Studiów Filozoficznych”, mimo tego, że stosowne zaproszenie do udziału w przedsięwzięciu zostało skierowane na adres KUL. Cały czas działało Polskie Towarzystwo Filozoficzne, na którego posiedzeniach prowadzono swobodne dyskusje. Odbyło się wiele konferencji naukowych, krajowych i międzynarodowych, na których marksiści wcale nie odgrywali decydującej roli. Kotarbiński został prezesem Międzynarodowego Instytutu Filozofii w 1957 r., a na pewno nie było to świadectwo katastrofy kulturowej czy zniewolenia przez marksizm.

Wprawdzie działalność wydawnicza była reglamentowana, ale i ona ilustruje tendencje wyżej wskazane. W 1952 r. wyszedł pierwszy tom monumentalnej serii Biblioteka Klasyków Filozofii, wydawanej przez Państwowe Wydawnictwo Naukowe, do której doszła Biblioteka Współczesnych Filozofów (początek w latach 80.; także publikowana przez PWN). Po 1956 r. wydano dzieła (zebrane lub pisma wybrane) Ajdukiewicza, Chwistka, Czeżowskiego, Elzenberga, Ingardena, Kotarbińskiego, Łukasiewicza, Tatarkiewicza i Twardowskiego, a więc czołowych filozofów już w okresie międzywojennym. Od lat 60. zaczęły się także ukazywać thumaczenia książek autorów polskich na języki obce, realizowane we współpracy ze znanymi zagranicznymi oficynami wydawniczymi (np. D. Reidel, North-Holland Publishing Company czy Pergamon Press). Wydano też wiele (pomijam tutaj pozycje $\mathrm{w}$ ramach wspo- 
mnianych dwóch serii) polskich przekładów książek filozofów zagranicznych (zachodnich), m.in. Ayera, Bergsona, Cassirera, Camusa, Carnapa, Deweya, Gilsona, Heideggera, Hempla, Jamesa, Kripkego, Marcela, Marcuse'a, Maritaina, Moore'a, Mouniera, Perelmana, Nagela, Poppera, Reichenbacha, Sartre'a, Russella, Teillarda de Chardin, Whiteheada czy Wittgensteina. Wprawdzie bywały kłopoty $\mathrm{z}$ cenzurą, ale dorobek publikacyjny $\mathrm{w}$ dziedzinie filozofii w Polsce w latach 1945-1989, zwłaszcza po 1956 r., jest nieporównywalny z tym, co działo się w innych krajach bloku wschodniego. Cień polityki był oczywiście także widoczny w polityce wydawniczej. Publikacja książek otwarcie antymarksistowskich była praktycznie niemożliwa. Obiecująca seria „z szachownicą”, powstała po 1956 r., upadła z powodu projektu wydania książki Poppera Społeczeństwo otwarte i jego wrogowie. Restrykcje polegały także na tym, że w Bibliotece Klasyków Filozofii nie ukazało się żadne dzieło św. Augustyna czy św. Tomasza z Akwinu. Ten stan rzeczy był częściowo rekompensowany przez wydawnictwa katolickie (np. PAX, Pallotinum, Znak), które publikowały literaturę z zakresu filozofii katolickiej (innej zresztą też), zarówno dawnej, jak i współczesnej, a od lat 80 . także przez oficyny drugiego obiegu (wspomniana książka Poppera ukazała się w taki właśnie sposób). Chociaż nie mam zamiaru utrzymywać, że było „łatwo i przyjemnie”, czy negować ograniczenia i represje mające miejsce nie tylko w latach 1949-1956, ale i później, to twierdzę (nie ja jeden zreszta), że filozofia polska utrzymała swój akademicki charakter w latach 1945-1989. Wedle dosadnego sformułowania Leszka Kołakowskiego, marksizm stał się trupem już w latach 70 . Świadomość tego stanu rzeczy coraz silniej kształtowała życie filozoficzne, także w Polsce. Z biegiem czasu było rzeczą ważniejszą być filozofem nauki, języka, kultury, prawa, człowieka, epistemologiem, ontologiem, estetykiem itd. niż marksistą lub nie-marksistą. Ten ostatni podział praktycznie stracił na znaczeniu w latach 80 . Krach marksizmu w Polsce i innych krajach po Jesieni Ludów nie był dla nikogo specjalnym zaskoczeniem. Encyklopedia konstatuje zniknięcie marksizmu na s. 14, ale nie wiadomo, dlaczego jest to uznane wyłącznie za fenomen filozofii polskiej (patrz jednak niżej w tej sprawie).

Nie było też tak, że nauczano wyłącznie marksizmu. Gdy studiowałem w Krakowie w latach 1960-1964, nie mieliśmy żadnych zajęć z marksizmu czy filozofii marksistowskiej poza ekonomia polityczną (1 rok) i marksistowską teorią rozwoju społecznego (1 semestr). Sam zacząłem uczyć filozofii w 1963 r. na Wydziale Prawa UJ. Przedmiot miał różne nazwy, z reguły z jakimś odniesieniem do marksizmu w tytule, np. „Podstawy filozofii marksistowskiej”, ale program mógł być kształtowany dość swobodnie przez nauczycieli akademickich, aczkolwiek program ogólny odpowiadał tytułowi, czyli kładł nacisk na doktrynę marksistowską. Zajęcia prowadziłem wedle struktury i w dużej mierze treści Zagadnień i kierunków filozofii Ajdukiewicza (książka 
ta nie została wprawdzie dopuszczona do sprzedaży w 1949 r., ale można ją było dostać na bazarach lub w antykwariatach, a w każdym razie wypożyczyć bez kłopotu z bibliotek), a część historyczna była oparta na Historii filozofii Tatarkiewicza. Podręczniki napisane z punktu widzenia marksizmu traktowałem jako pomocnicze; dodam jednak, że niektóre $\mathrm{z}$ nich nie nasuwały większych obiekcji z merytorycznego punktu widzenia, przynajmniej w pewnych partiach, i mogły być polecane z czystym sumieniem. Poglądy marksistowskie były poruszane jako jedne z wielu. Przez 16 lat, bo tyle uczyłem filozofii jako przedmiotu pomocniczego, nikt nie zwracał mi uwagi, że moja dydaktyka była niewłaściwa. Nie twierdzę, że praktyka, którą stosowałem, i tolerancja dla niej były powszechne, ale, o ile mi wiadomo, występowały częściej niż tylko marginalnie. W 1982 r. zupełnie niespodziewanie zlikwidowano filozofię marksistowską jako przedmiot obowiązkowy i wprowadzono możliwość wyboru przedmiotów humanistycznych. Nieźle rozwijał się studencki filozoficzny ruch naukowy, zarówno ogólnopolski, jak i lokalny, w którym uczestniczyli także studenci z KUL (organizowali popularne w Polsce tygodnie filozoficzne), a dwa sympozja (Zakopane 1961 r., Bukowina Tatrzańska 1962 r.) odbiły się szerokim echem $\mathrm{w}$ całym środowisku filozoficznym $\mathrm{z}$ uwagi na bardzo gorące dyskusje, m.in. z udziałem Ingardena, Kołakowskiego i Schaffa. Antoni Stępień wspomina (t. 2, s. 67) o spotkaniach studentów UW i KUL w Warszawie i Lublinie w 1957 r., na których był obecny. Wspomina je jako ,[pełne] obopólnych zadziwień i nieporozumień" i lokuje w ramach polemik marksistowsko-katolickich. Z natury rzeczy (byłem wtedy jeszcze licealistą) nie brałem udziału w tych imprezach. Od kolegów z UW, którzy uczestniczyli, wiem, że bynajmniej nie sprowadzały się do dyskusji pomiędzy marksistami a neotomistami. Dobrze pamiętam natomiast sympozjum w Zakopanem $\mathrm{z}$ udziałem trzech osób z KUL, w tym ówczesnego adiunkta Antoniego B. Stępnia, przepięknie grającego wieczorami jazz na fortepianie, czym wzbudzał zasłużony aplauz. Ważniejsze jest jednak to, iż obrady odbywały się pod znakiem dyskusji o filozofii i jej problemach, a nie tylko o marksizmie i katolicyzmie. Jasne, że także o tych orientacjach, ale nie była to tendencja dominująca. Szkoda, że Stępień o tym nie wspomniał. Może pamięta dyskusję nad referatem młodego asystenta z KUL na temat pojęcia prawdy koniecznej, a jeśli tak, powinien sobie również przypomnieć, że dyskusja nad tym wystapieniem w ogóle nie dotykała marksizmu, a koncentrowała się na tym, czy poglądy Arthura Papa w kwestii zdań koniecznych są trafne, czy nie.

Niemniej jednak nad wszystkim, co działo się w filozofii polskiej w tym czasie unosił się postulat, czasem formułowany wyraźnie lub też niekiedy tylko dawany do zrozumienia, że chociaż nie ma zakazu zajmowania się tym, czym kto chce, marksizm jest najważniejszy w filozofii. W tych ramach funkcjonował pewien kompromis, którego esencja polegała na tolerowaniu przez władzę 
postawy niemarksistowskiej w zamian za rezygnację $\mathrm{z}$ anty-marksistowskiej, przynajmniej wyrażanej otwarcie. Wszyscy, a nie tylko szkoła lubelska, mieli świadomość, że cenzura nie zasypia gruszek w popiele i starannie przygląda się każdej planowanej publikacji, nie tylko katolickiej. Wszelako zdecydowana większość poczynań filozoficznych w Polsce w rozważanym okresie nie ograniczała się do posunięć w ramach odgórnie zadanej gry i nie była dyktowana lękiem wobec władzy czy oportunizmem wobec niej, ale wypływała ze szczerego przekonania do głoszonych przez siebie idei, a także tendencji do ich obrony i ulepszania, po to m.in., aby je uczynić atrakcyjnymi dla adwersarzy. Dotyczyło to zarówno marksistów, jak i niemarksistów. $Z$ rozmaitych powodów, także omówionych wyżej, dla zrozumienia historii filozofii polskiej po 1945 r. ważne są co najmniej cztery następujące okoliczności, wpływające na stosunkowo znaczny pluralizm filozofii polskiej w latach 1945-1989:

(1) orientacje w ramach filozofii marksistowskiej w Polsce, która bynajmniej nie była jednolita;

(2) stosunek filozofów marksistowskich do innych kierunków filozoficznych, nie wyczerpujący się tylko w krytyce;

(3) stosunek niemarksistów do marksistów, wcale nie apologetyczny;

(4) mapa filozofii polskiej.

W związku z (4) trzeba uwzględnić działalność tych filozofów, którzy ukształtowali swoje poglądy przed 1945 r. i w większości przypadków nie zmienili ich w nowej rzeczywistości, obecność silnej filozofii katolickiej (chociaż krytykuję Encyklopedię za stronniczość, jestem jak najdalszy od niedoceniania roli KUL i innych ośrodków myśli chrześcijańskiej w kształtowaniu pluralistycznej filozofii w Polsce po II wojnie światowej), różnice i polemiki w samym marksizmie, czyli punkt (1), fakt, że wielu marksistów odeszło od tego nurtu jeszcze przed 1989 r., stając się jego surowymi krytykami oraz wspomniane już organizowanie pracy filozoficznej bardziej wokół problemów niż kierunków.

Encyklopedia informuje o czynnikach (1)-(4). Można się o tym przekonać z lektury takich haseł rzeczowych, jak „Lubelska szkoła filozoficzna” (t. 1; autorzy: A. Maryniarczyk, M.A. Krapiec; jest to przedruk z t. 6 PEF), „Marksistowski materializm” (t. 2; autor: A.B. Stępień), „Marksizm polski w dialogu” (t. 2; autor: A.B. Stępień) i „Polska filozofia” (t. 2; autor: A.B. Stępień), a także $\mathrm{z}$ haseł osobowych. Z grubsza rzecz biorąc, po pierwsze, lubelska szkoła filozoficzna jest przedstawiona jako podstawowy bastion niezależnej filozofii w Polsce, po drugie, jeśli marksizm był krytykowany, to przede wszystkim przez filozofów katolickich (choć trzeba odnotować hasło „Kołakowskiego krytyka marksizmu", aczkolwiek argumenty wysunięte przez Kołakowskiego nie są 
przytaczane w innych miejscach poświęconych krytyce filozofii marksistowskiej), a po trzecie, polemiki marksistów były skierowane przede wszystkim przeciwko katolikom, głównie neotomistom. Tak więc narracja Encyklopedii obraca się wokół osi wyznaczonej przez opozycję: (zły) marksizm - (dobra) szkoła lubelska. Nawiasem mówiąc, Encyklopedia pomija lub zdecydowanie pomniejsza rolę innych ośrodków filozofii katolickiej w Polsce, w szczególności Akademii Teologii Katolickiej w Warszawie czy Papieskiej Akademii Teologicznej (obecnie Papieski Uniwersytet Jana Pawła II) w Krakowie (ciekawe, że pominięty został opór władz w uznaniu tej uczelni w latach 80 ., co być może zmniejszyłoby wrażenie szczególnych cierpień KUL), zwłaszcza jej Ośrodka Badań Interdyscyplinarnych. Tak więc Encyklopedia jest niezbyt fair nawet wobec własnego, tj. katolickiego środowiska.

Ponieważ wyróżniona rola szkoły lubelskiej w obrazie filozofii polskiej malowanym przez Encyklopedię została już wyżej udokumentowana, dalej zajmę się krytyką marksizmu i marksizmem w dialogu (interesują mnie nie kwestie treściowe, w sensie zasadności podnoszonych argumentów, ale, by tak rzec, funkcjonalne). Oba hasła zazębiają się ze sobą, gdyż pierwsze także informuje o wewnętrznych i zewnętrznych polemikach marksistowskich, a drugie zawiera elementy krytyki marksizmu; te motywy są również obecne w ogólnym artykule o filozofii polskiej. Stępień szeroko krytykuje marksistowski materializm z punktu widzenia neotomizmu, a argumenty formułowane z punktu widzenia innych koncepcji są przytaczane sporadycznie, np. Ajdukiewicza dotyczące sprzeczności i zmiany. To dość osobliwa praktyka, ponieważ aby rozwinąć jedną z wcześniejszych uwag, powszechne encyklopedie filozoficzne, ogólne czy też dotyczące tematów szczególnych, nie są redagowane dla eksponowania polemik prowadzonych z punktu widzenia jednego wybranego stanowiska, ale mają zaznajomić czytelnika z dyskusją na dany temat i przedstawić argumenty padające $\mathrm{z}$ różnych stron, a także odpowiedzi na zarzuty. Jeśli porównamy to, co o marksizmie i materializmie znajduje się w PEF i w Encyklopedii, łatwo skonstatujemy, że o ile pierwsza pozostaje w zwyczajowych granicach encyklopedycznych, to druga traktuje ten sam temat w sposób zdecydowanie szczególny, jeśli chodzi o siłę krytyki. Z dość oczywistych powodów Encyklopedia, jako że jest poświęcona filozofii polskiej, nie zajmuje się zbyt wiele poszczególnymi kierunkami filozoficznymi, oczywiście z wyjątkiem tomizmu lubelskiego. Omawia np. konwencjonalizm radykalny Ajdukiewicza i fenomenologię w Polsce. Oba hasła zostały napisane przez autorów związanych z KUL (B. Czernecką-Rej i A.B. Stępnia). Mają typowy charakter encyklopedyczny, w szczególności prezentują argumenty pro i contra wysuwane w Polsce. Podobny charakter mają artykuły dotyczące poszczególnych marksistów, niezależnie od tego, czy powstały w kręgu szkoły lubelskiej, czy innego środowiska. Hasło „Marksistowski materializm” jest zatem wyjątko- 
we w swojej warstwie krytycznej, aczkolwiek, rzecz jasna, także przedstawia odnośne poglądy marksistów jako pewną propozycję metafizyczną.

Krytyka Stępnia jest totalna i odmawia filozofii marksistowskiej jakiejkolwiek wartości, aczkolwiek można w niej znaleźć pewne niespójności (patrz niżej). Nie zawsze tak było. Książka tego samego autora Wprowadzenie do filozofii miała trzy wydania przed 1989 r., a każde z nich zawiera informacje o marksizmie. Są one czysto sprawozdawcze, bez jakiejkolwiek polemiki z filozofią marksistowską. Powie ktoś, że otwarta krytyka marksizmu była w czasach komunistycznych niemożliwa. Stępień też to podkreśla (t. 2, s. 66), powiadając, że polemiki tomistów z marksistami rzadko mogły liczyć na publikację, natomiast prowadzone były przez „pozytywny wykład własnego stanowiska". Nie ma powodu, aby kwestionować takie tłumaczenia. Można zrozumieć, że polscy filozofowie katoliccy byli nader ostrożni w formułowaniu treści krytycznych wobec marksizmu, nie tylko w druku, ale również w publicznych wystapieniach na sympozjach i konferencjach (sąd ten formułuję na podstawie własnego doświadczenia). To jednak znaczy, że tomiści, także ze szkoły lubelskiej, zachowywali się tak, jak inni filozofowie niemarksistowscy w Polsce, tj. uczestniczyli we wspomnianej wyżej grze odróżniającej poglądy niemarksistowskie od antymarksistowskich. Sięgam do książki (zbioru artykułów) Wobec filozofii marksistowskiej. Polskie doświadczenia, pod red. A.B. Stępnia. Po raz pierwszy została wydana w Rzymie w 1987 r., a w Polsce trzy lata później, nakładem Towarzystwa Naukowego Katolickiego Uniwersytetu Lubelskiego - w 1990 r., a więc już po zmianach ustrojowych. Wszystkie artykuły (autorzy: A.B. Stępień, M.A. Krąpiec, W. Chudy, J.W. Gałkowski, T. Styczeń i A. Szostek, Z.J. Zdybicka i S. Kamiński) zawierają silne akcenty polemiczne wobec marksizmu. W samej rzeczy, Stępień w omawianym haśle z Encyklopedii powtórzył, i to nawet verbatim, sformułowania użyte w artykułach „Materializm dialektyczny - filozofia marksizmu” i „Wobec marksistowskiej teorii człowieka" w książce Wobec filozofii marksistowskiej, s. 37-60 i 61-79. Krytyka w Encyklopedii jest zaostrzona przez to, że o ile w artykułach z 1987 r. pewne prace marksistowskie są traktowane jako oryginalne i pogłębione (s. 51), to pochwały te całkowicie znikły w Encyklopedii.

Nie mam najmniejszego zamiaru bronić materializmu marksistowskiego. Wskazuję tylko na uwarunkowania krytycznych publikacji na temat marksizmu. Jak sam Stępień informuje (Oblicza dialogu. Z dziejów i teorii dialogu: chrześcijanie-marksiści w Polsce, pod red. A.B. Stępnia i T. Szubki, Redakcja Wydawnictw Katolickiego Uniwersytetu Lubelskiego, Lublin 1992, s. 182; jeszcze wrócę do tej pozycji), książka Wobec filozofii marksistowskiej „była od razu pisana dla wydawcy zagranicznego” i z przekonaniem, że nie zostanie dopuszczona przez cenzurę na rynek krajowy, co zresztą miało miejsce. Chwała autorom, że nie ugięli się pod presją cenzury i nie przystali 
(tak sądzę) na złagodzenie krytyki, ale wiele nie ryzykowali, skoro książka ukazała się na Zachodzie (pod koniec lat 80. władza na to machała ręka). Sięgam do wspomnianej wyżej publikacji o obliczach dialogu, stanowiącej plon sympozjum w Kazimierzu nad Wisłą odbytego we wrześniu 1989 r., w którym udział wzięli filozofowie z KUL (A.B. Stępień, J. Herbut, S. Kowalczyk, W. Chudy, J.W. Gałkowski, A. Szostek, Cz. Teklak) oraz marksiści (J. Kuczyński, D. Tanalski, W. Mackiewicz, T. Płużański). Na tom składają się referaty (nie tylko wygłoszone w Kazimierzu) i dyskusja panelowa na tematy wiążące się z tytułem całości. Porównanie dat wskazuje, że krajowe wydanie książki Wobec filozofii marksistowskiej było przygotowywane (w druku), gdy sympozjum w Kazimierzu miało miejsce; przytoczona informacja Stępnia to właśnie dokumentuje. Ton tekstów „lubelskich” zamieszczonych w Obliczach dialogu jest inny niż w tomie z 1987 r. Rzecz nie w tym, iż tomiści uznali, że ich filozofia ma punkty wspólne z marksizmem, czy też że oba kierunki dadzą się uzgodnić w kwestiach podstawowych. Wszelako marksizm jest traktowany jako normalny kierunek filozoficzny. Stępień w „Posłowiu” (s. 227-228) wskazuje na kryzys filozofii marksistowskiej, ale kończy tak:

[...] właśnie teraz, kiedy względy ideologiczno-polityczne odchodzą na drugi plan, kiedy nie ma cenzury i nacisków ,administracyjnych”, jest czas na spokojną, fachową analizę, na kameralne, lecz bardziej dogłębne i obiektywne dyskusje na temat wartości materializmu dialektycznego i historycznego, na temat różnych aspektów dialogu: chrześcijanie-marksiści.

A więc dialog filozoficzny był jednak możliwy zdaniem szkoły lubelskiej. Być może ta różnica wzięła się stąd, że Oblicza dialogu stanowią (jak informuje nota na odwrotnej stronie tytułowej) pracę wykonaną w ramach programu badawczego K-RP-15/86 „Filozofia pokoju”, kierowanego przez Janusza Kuczyńskiego. Tak więc szkoła lubelska współpracowała $\mathrm{z}$ marksistami w konkretnych zagadnieniach. To nie jest żaden wytyk czy zarzut, a tylko odnotowanie zależności stosunku do marksizmu od konkretnych okoliczności.

Zaznaczona niejednoznaczność stosunku szkoły lubelskiej do marksizmu jest śladowo obecna w haśle „Marksizm polski w dialogu”. Zaczyna się ono od wskazania na „próby dyskusji różnych formacji filozoficznych z marksistami”. Dalszy tekst jest rozbity na trzy części. W pierwszej, dotyczącej lat 1945-1949 i 1950-1956, omówione są normalne polemiki (pierwsze lata powojenne) oraz ofensywa ideologiczna lat stalinowskich, którą trudno nazwać dialogiem. Część druga dotyczy dyskusji wśród marksistów po 1956 r., głównie pomiędzy tzw. orientacją scjentystyczną a tzw. nurtem antropologicznym. I to trudno nazwać dialogiem, ponieważ kontrowersje były ostre. Część trzecia zajmuje się wyłącznie dialogiem marksistowsko-chrześcijańskim (dokładniej: katolickim). Stępień powtarza tutaj tezy ze swojego artykułu „Rys rozwoju filozo- 
fii marksistowskiej i problem dialogu filozoficznego $\mathrm{z}$ marksizmem od roku 1945", zamieszczonego w zbiorze Wobec filozofii marksistowskiej, s. 21-36. Można je uznać za sprzeciw wobec szukania zbyt daleko idących podobieństw czy postaw praktycznych (jak w ujęciu J. Tischnera) pomiędzy marksistami a filozofami chrześcijańskimi. W samej rzeczy, niektórzy marksiści i niektórzy filozofowie chrześcijańscy traktowali polską scenę filozoficzną końca lat 80 . jako podzieloną niemal dychotomicznie pomiędzy kierunki przez nich reprezentowane. Stępień zaleca ostrożność w ustalaniu podobieństw, np. w kwestii definicji prawdy czy realizmu, oraz postuluje swobodną (tj. nieograniczoną cenzurą) dyskusję o podstawowych zasadach obu systemów, które są fundamentalnie odmienne. Nie wyklucza jednak dialogu poważnego i rzetelnego. $\mathrm{Na}$ tym tle koniec hasła w Encyklopedii (t. 2, s. 71) jest zaskakujący w stosunku do treści poprzedzających:

Filozofia marksistowska w Polsce, ściśle powiązana ze swym zapleczem polityczno-administracyjnym i spełniająca funkcje ideologiczne po wydarzeniach 1989 i roku następnym musi się na nowo odnaleźć. Czas pokaże, czy przybierze nową postać (czy postacie), czy też przestanie być jednym z głównych kierunków w powojennej Polsce.

Gdyby te słowa, korespondujące z „Posłowiem” z książki Oblicza dialogu, zostały napisane w 1990 r., można by je uznać za jakąś diagnozę i prognozę, aczkolwiek dla wielu obserwatorów życia umysłowego w Polsce było raczej oczywiste, że marksizm przestał być ,,jednym z głównych kierunków w powojennej Polsce”. Straciły jednak wszelką aktualność znacznie wcześniej niż w 2011 r. Nie widać prób odnalezienia się marksizmu na nowo i nie ma znamion jakiejś konieczności, aby to nastapiło. Dlaczego zatem konsultant merytoryczny całej Encyklopedii, chyba znający pogląd jej redaktora naczelnego o zniknięciu marksizmu i marksistów ze współczesnej filozofii polskiej, formułuje taką dziwaczną opinię? O ile nie jest to zwyczajne przeoczenie, nasuwa się tylko jedno wytłumaczenie. Otóż wysuwanie opozycji pomiędzy marksizmem a szkołą lubelską jako lunety dla oglądania filozofii polskiej po II wojnie światowej wygląda na próbę podniesienia prestiżu tej drugiej. Stąd krytyka tego, co na krytykę już nie bardzo zasługuje i oczekiwanie, że stare dobre czasy, stwarzające okazję do pryncypialnego dialogu, jeszcze wróca, aczkolwiek już bez autorytarnej administracyjnej otoczki. W gruncie rzeczy pomysł to chybiony z merytorycznego punktu widzenia, bo chyba nikt nie jest dzisiaj zbyt zainteresowany kolejnym wskazaniem, że prawa dialektyki są nader mętne, a materialistyczna (nie tylko marksistowska) interpretacja świadomości ciagle wysoce problematyczna.

Jeśli nawet rozpatrywać historię filozofii polskiej po 1945 jako konfrontację z marksizmem, prawda jest taka, że neotomizm nie był ani chronologicznie 
pierwszą, ani rzeczowo najważniejszą formacją w tym względzie. Wystarczy spojrzeć na współczesną filozoficzną mapę Polski, aby przekonać się, że tzw. (na wyrost) polska szkoła filozofii klasycznej jest tylko lokalnym fragmentem nawet $\mathrm{w}$ ramach myśli katolickiej, a jej rzeczywiste wpływy daleko ustępują znaczeniu fenomenologii czy filozofii analitycznej w naszym kraju. Wszelako, ale to już inna sprawa, stosunek do problemów filozoficznych dostarcza znacznie sprawniejszej optyki dla analizy tego, co stało się w polskiej myśli filozoficznej po 1945 r., niż korzystanie z bardzo grubo ciosanego kontrastu używanego w Encyklopedii. Niech więc teraz szkoła lubelska nie pozuje na jedyną czy też główną niezależną formację filozoficzną w powojennej Polsce, totalnie odseparowaną od tego kierunku. Prawda jest taka, że myśl katolicka, przy wszystkich ograniczeniach administracyjnych, zwłaszcza cenzuralnych, miała większe możliwości artykulacji swej filozofii niż inne kierunki. W najczarniejszych, tj. stalinowskich czasach, ukazały się dwa tomy „Roczników Filozoficznych", II-III (1948-1950) i IV (1955), i kilka książek; przedstawiciele innych kierunków mogli tylko marzyć o czymś takim. Potem produkcja filozoficznych publikacji katolickich (także np. wydawanych przez ATK) była w miarę swobodna pod warunkiem, że nie były jawnie antymarksistowskie, a więc wedle ogólnej reguły dotyczącej wszystkich. Filozofowie katoliccy publikowali też w pismach „oficjalnych”, w szczególności w „Studiach Filozoficznych", i nie sądzę, aby decydowali się na to z powodu nieodpartego zniewolenia.

Nikt nie oczekiwał, że neotomiści staną się marksistami nawet w ograniczonym zakresie, więc nie powinni szczycić się własną niezależnością, a reklamowanie jej jako wyjątkowej mija się z prawdą. Filozofia katolicka była treściowo i organizacyjnie niezależna od marksizmu, nie tylko własnym wysiłkiem, godnym najwyższego uznania, ale także na mocy politycznej decyzji ze strony władzy. W sumie, szkoła lubelska nie powinna epatować radykalną, acz spóźnioną krytyką marksizmu w wydawnictwach typu encyklopedycznego, aby dokumentować swoją niezłomność. Dla usunięcia ewentualnych możliwych nieporozumień dodam, że status filozofii katolickiej w Polsce nie był kwestionowany $\mathrm{w}$ naszym środowisku filozoficznym, może poza grupa ortodoksyjnych marksistów. Wizyty w KUL, zwłaszcza w latach 1980, były wielką atrakcją, właśnie $\mathrm{z}$ uwagi na atmosferę niezależności panującą $\mathrm{w}$ tym miejscu. Uwagi powyższe dotyczą tylko i wyłącznie sfery doktrynalnej, by tak rzec. Wiadomo, że władze imały się rozmaitych sposobów ograniczających działalność uczelni katolickich, w postaci ograniczania liczby kierunków oraz limitów przyjęć na studia czy zwlekania z zatwierdzaniem habilitacji i nadawaniem tytułów profesora. W ogólności marksiści mieli szybszą ścieżkę awansową, ale ograniczenia dotykały nie tylko katolików, a także były stosowane wobec uczelni ,świeckich”, np. po marcu 1968 r. (zamknięcie 
filozofii w Uniwersytecie Warszawskim). Nawet jeśli restrykcje organizacyjno-administracyjne wobec uczelni katolickich były większe i bardziej długotrwałe niż wobec szkolnictwa wyższego działającego w sektorze publicznym, te pierwsze nie znajdowały się w sytuacji wyjątkowej, nie mówiąc o tym, że ich sytuacja z biegiem czasu poprawiała się. Z drugiej strony, aby powtórzyć raz jeszcze, filozofowie katoliccy mieli na ogół lepsze możliwości artykulacji własnego stanowiska niż inni niemarksiści. Można zrozumieć, że wspomniana wyżej ostrożność czy wstrzemięźliwość filozofów katolickich w formułowaniu krytycznych argumentów wobec marksizmu była spowodowana obawą przed nasileniem represji administracyjnych za takowe poczynania, a nawet usprawiedliwić taką postawę, ale czynienie z niej powodu do chwały jest przesadą.

Redaktorzy encyklopedii, historii filozofii współczesnej czy słowników filozoficznych zawierających biogramy borykają się z problemem, kogo uwzględnić, a kogo pominąć. Encyklopedia poradziła sobie z tym w ten sposób, że przyjęła ukończenie (w roku wydania dzieła) 80 lat jako kryterium uhonorowania danego filozofa osobnym hasłem. W Suplemencie do PEF „wiekomierz" był nieco łagodniejszy, mianowicie przekroczenie 79 lat, co zapewne było podyktowane tym, aby jacyś prominenci szkoły lubelskiej mogli zostać uwzględnieni. Oto lista haseł o żyjących (w momencie oddania Encyklopedii do druku) filozofów polskich (mam nadzieję, że nikogo nie pominąłem): Bronisław Baczko, Czesław Bartnik, Zygmunt Bauman, Bohdan Bejze, Bronisław Burlikowski, Zdzisław Cackowski, Bronisław Dembowski, Marian Dobrosielski, Juliusz Domański, Seweryn Dziamski, Bohdan Dziemidok, Mieczysław Gogacz, Maria Gołaszewska, Andrzej Grzegorczyk, Leon Gumański, Józef Herbut, Marian Jaworski, Jerzy Kmita, Stanisław Kowalczyk, Sław Krzemień-Ojak, Zbigniew Kuderowicz, Zdzisław Kuksewicz, Tadeusz Kwiatkowski, Mieczysław Lubański, Witold Marciszewski, Mieczysław Michalik, Edmund Morawiec, Andrzej Nowicki, Jerzy Pelc, Andrzej Półtawski, Jerzy Prokopiuk, Marian Przełęcki, Adam Rodziński, Henryk Skolimowski, Antoni B. Stępień, Władysław Stróżewski, Jan Such, Jan Szmyd, Tadeusz Ślipko, Dionizy Tanalski, Anna Teresa Tymieniecka, Andrzej Walicki, Jerzy J. Wiatr, Bogusław Wolniewicz, Zofia Zdybicka i Stanisław Ziemiański. Dla 5 osób uczyniono wyjątek, mianowicie dla Dziamskiego, Dziemidoka, Herbuta, Kowalczyka i Stróżewskiego. Z drugiej strony, przeoczono Janusza Kuczyńskiego, Włodzimierza Lawniczaka, Ryszarda Panasiuka, Adama Sikorę (zmarł w 2011 r., zapewne po ukończeniu Encyklopedii), Stanisława Józefa Sokołowskiego, Stanisława J. Surmę i Ryszarda Wójcickiego, chociaż osiągnęli oni w filozofii więcej niż niejeden z tych, którzy mają własne hasła w Encyklopedii. Przeoczenia są nieuniknione, ale tych, które znalazłem (z wyjątkiem Surmy), łatwo było uniknąć zaglądając do Stownika filozofów polskich pod red. B. Andrze- 
jewskiego i R. Kozłowskiego, Wydawnictwo Naukowe UAM, Poznań 2006. Każdy, kto jako tako obserwuje współczesną filozofię polską, raczej nie uzna listy żyjących filozofów ułożonej wedle personalnych haseł w Encyklopedii za zbyt reprezentatywną. Niemniej jednak, ponieważ biologia nie preferuje kierunków ani szkół, proporcje wyprowadzone z listy haseł osobowych są znacznie bardziej realistyczne dla mapy filozofii w Polsce niż te, które wypływają $\mathrm{z}$ hasła napisanego przez Stępnia, bo wynoszą 12 (szkoła lubelska plus duchowni z nią niezwiązani) do 49 (ogół), o ile pominąć wyjątki i wliczyć pominiętych, lub 14 do 52, gdy pozostać przy listach Encyklopedii. Od razu zaznaczam, że nie kieruje mną mój własny interes czy też zawiedziona ambicja. Gdy powiedziałem jednemu z czołowych polskich filozofów (o renomie międzynarodowej i zarazem katolikowi), że zgodnie z kryteriami wiekowymi przyjętymi dla Encyklopedii nie mamy w niej własnych haseł, dość radośnie odrzekł (akurat siedzieliśmy przy obiedzie): „Trzeba to oblać”. I chyba miał rację, bo nieobecność (w sensie bycia osobno uhonorowanym) w Encyklopedii nie sprawia poczucia dyskomfortu.

Tendencję ideową (może nawet ideologiczną) Encyklopedii dodatkowo zilustruję na bardzo konkretnym przykładzie, mianowicie hasła o polskich zjazdach filozoficznych (t. 2, s. 887-893; autorka: M. Nawracała-Urban). Autorka omawia trzy zjazdy przedwojenne (w latach 1923, 1927 i 1936, odpowiednio we Lwowie, Warszawie i Krakowie) oraz pięć zjazdów powojennych: 1977 - Lublin, 1987 - Kraków, 1995 - Toruń, 2004 - Szczecin, 2008 - Warszawa. Zjazdy przedwojenne zostały potraktowane przez autorkę czysto sprawozdawczo, bez formułowania komentarzy czy ocen. Podobnie ma się sprawa z prezentacją zjazdów w Szczecinie i Warszawie, ale inaczej jest w odniesieniu do zjazdu lubelskiego, krakowskiego i toruńskiego. Zajmę się tylko tymi trzema ostatnimi. Omówienie spotkania w 1977 r. jest poprzedzone odwołaniem się do artykułu Stępnia o stanie i potrzebach filozofii polskiej, w którym autor zwrócił uwagę na rolę ośrodków myśli chrześcijańskiej w Polsce, skupionej w KUL i ATK. Nie ma powodu, aby kwestionować ten postulat, ale podobne były wysuwane także wobec innych orientacji niemarksistowskich od 1956 r. Nie bardzo jednak wiadomo, dlaczego stan i potrzeby filozofii chrześcijańskiej miały odgrywać jakąś specjalną rolę w przygotowaniach do Ogólnopolskiego Zjazdu Filozoficznego (taka była jego oficjalna nazwa). Dalej następuje streszczenie obrad, z jednym fragmentem godnym specjalnej uwagi. Autorka (s. 890) powiada (jest to cytat), że wedle Garewicza „nieporozumieniem jest uprawianie historii filozofii polskiej”. Wszelako pełna wypowiedź, która zresztą wzbudziła sprzeciwy (hasło o tym informuje), była następująca (cytuję za: R. Jadczak, Polskie zjazdy filozoficzne, Uniwersytet Mikołaja Kopernika, Torun 1995, s. 92; M. Nawracała-Urban korzystała z tego samego źródła): 
[można] uprawiać historię filozofii i historię filozofii w Polsce, ale nieporozumieniem jest uprawianie historii filozofii polskiej. Na pytanie: Jakiej filozofii potrzebują Polacy? odpowiedzią może być tylko: filozofii tout court.

Różnicy nie warto nawet komentować, bo manipulacja jest aż nadto widoczna, aczkolwiek trzeba zwrócić uwagę, że redukcja wypowiedzi Garewicza koresponduje z ogólnikowym (patrz wyżej) stwierdzeniem Maryniarczyka o micie braku filozofii polskiej. Hasło kończy się odwołaniem do kolejnej wypowiedzi Stępnia, że zjazd nie spełnił swego zadania, ponieważ „dominowała prawie wyłącznie filozofia marksistowska". Jadczak w cytowanej książce podaje listę referatów. Było ich 81, w tym 36 na pewno niemarksistowskich (nie wliczam w to wystapień autorów marksistowskich, które nie dotyczyły marksizmu). Faktem jest, że szkoła lubelska była słabo reprezentowana, ale ponieważ nie znam powodów tego stanu rzeczy (być może dystansowała się z powodu zamierzonego niewchodzenia $\mathrm{w}$ drogę marksizmowi), powstrzymam się od komentarza. Jak by nie było, opinia o prawie wyłącznej dominacji marksizmu na zjeździe lubelskim jest daleka od prawdy, aczkolwiek kierunek ten był najbardziej widoczny na tej imprezie.

Relacja ze zjazdu w Krakowie zaczyna się wskazaniem na reprezentację KUL (7 osób; faktycznie 8, gdyż autorka pominęła S. Mazierskiego) jako tzw. uczelni niezależnej. M. Nawracała-Urban chyba uważa, że jest to jakiś ewenement, bo nie wspomniała o udziale niezależnych filozofów $\mathrm{z}$ innych ośrodków. Trudno jednak zrozumieć, dlaczego przyjazd filozofów z lubelskiej szkoły miałby być czymś szczególnym. Wszyscy byli oficjalnymi pracownikami swojej uczelni, niektórzy profesorami tytularnymi z rąk Przewodniczącego Rady Państwa, a w tym gronie znajdowali się również kawalerowie wysokich odznaczeń państwowych (szczegółowy wykaz honorów M.A. Krąpca znajduje się w haśle o nim; jest to zapewne kolejny przykład zniewolenia politycznego). Zjazd w sumie został oceniony przez autorkę pozytywnie, aczkolwiek na końcu swej relacji z tego wydarzenia zauważa, iż „organizatorzy nie ustrzegli się uwikłań politycznych”. Wszelako szkoda, że nie poinformowała o nich bliżej. Sam pamiętam dwie okoliczności warte odnotowania. Po pierwsze, ortodoksyjni marksiści z grupy J. Ładosza odmówili udziału w zjeździe krakowskim, ponieważ zasadniczo odbiegał od ducha partyjności filozofii. Nikogo to zresztą zbytnio nie zmartwiło. Po drugie, o. J.M. Bocheński, przebywający wówczas w Krakowie, nie zgodził się na udział w zjeździe. Powiedział mi, że obawia się wykorzystania swojej obecności dla celów politycznych. Nie było więc tak, że zjazd krakowski nie miał kontekstu politycznego. Jeśli jednak ktoś porusza tę kwestię, winien wyraźnie zaznaczyć, o co mu chodzi, a nie, jak to czyni M. Nawaracała-Urban, ograniczać się do mętnych aluzji. W Krakowie wygłoszono 153 referaty, w tym co najmniej 92 niemarksistowskie. 
KUL był reprezentowany przez 8 referentów, a ATK przez 4. Ponieważ nie było żadnych ograniczeń w uczestnictwie, raczej skromna reprezentacja szkoły lubelskiej, przynajmniej w porównaniu z pretensjami do bycia zauważonă, na pewno nie była spowodowana przez jakieś tajemnicze uwikłania polityczne, tym bardziej, że sytuacja uczelni katolickich była już wtedy raczej normalna.

Zjazd w Toruniu spotkał się najbardziej surową oceną w haśle napisanym przez M. Nawracałę-Urban. Zaczyna się od krótkich uwag o strukturze i liczbie uczestników (wygłoszono prawie 700 referatów, czyli blisko 4 razy więcej niż w Krakowie i 7,5 raza więcej niż w Lublinie). Potem informuje o tym, że w czasie uroczystości otwarcia odczytano m.in. przesłanie Jana Pawła II do uczestników, w którym była mowa o filozofii jako powołanej do służenia Prawdzie. Dalej przechodzi do wskazania 4 głównych orientacji zjazdowych, mianowicie filozofii logicznej, filozofii jako zjawiska społecznego lub kulturowego (np. u Z. Zdybickiej), historii filozofii i filozofii jako rodzaju ekspresji życiowej. Od razu widać, że M. Nawracała-Urban miesza dyscypliny filozoficzne, rozumienia filozofii, funkcje filozofii i typy filozofii. Dalej autorka wspomina o wielkich nadziejach wobec zjazdu jako pierwszego po zmianach w 1989 r. oraz o referacie R. Wójcickiego jako zarzucającym powojennej filozofii polskiej odwrócenie się od poszukiwania prawdy. I formułuje taką oto ocenę ogólną (s. 892):

Zastrzeżenia budziła programowa koncepcja zjazdu. Tytuły i abstrakty referatów wskazywały na duże rozproszenie tematyki i nieodpowiednie pogrupowanie w sekcjach. Ustalenie wykładów ogólnych w obrębie jednej orientacji zafałszowywało pozycję innych nurtów, jak tomizm i fenomenologia. Dominował nurt szeroko rozumianej filozofii pozytywizującej i analitycznej. Brakowało czasu na rzetelną dyskusję, służącą przełamywaniu barier między określonymi szkołami.

Za podsumowanie (s. 892) służą autorce słowa Stępnia zawarte w jego sprawozdaniu z przebiegu obrad, że zjazd toruński wypełnił różne niewielkie role kongresów tego typu, ale nie „tego wielkiego zadania, które było potrzebne i na które wskazał w swym przesłaniu też filozof polski Jan Paweł II”.

Ponieważ uczestniczyłem w pracach Komitetu Programowego powołanego dla przygotowania zjazdu w Toruniu, pozwolę sobie na szersze skomentowanie uwag M. Nawracały-Urban. Kwestia struktury obrad i zaproszonych gości była na początku sporna. Proponowano, aby referaty ogólne wygłosili wyłącznie polscy filozofowie mieszkający za granicą. Potem jednak odstapiono od tego pomysłu. Zdecydowaliśmy się na niewiele referatów ogólnych, tj. wygłoszonych dla wszystkich uczestników. Zjazd miał otwierać Leszek Kołakowski, ale uległ groźnemu wypadkowi i do Torunia nie mógł przyjechać. Ostateczny wybór padł na Henryka Hiża jako referenta inaugurującego zjazd. 
Przedstawił on referat „Rozumowania w polszczyźnie”. Innymi referentami „ogólnymi” byli: Jerzy Kmita („Językowe formowanie świata”), Marian Przełęcki („Racjonalistyczne dziedzictwo szkoły lwowsko-warszawskiej”), Bogusław Wolniewicz („Filozoficzne aspekty kary głównej”) i Zygmunt Ziembiński („O sprawiedliwości między ludźmi i o sprawiedliwości między narodami”). Zaproszenie wysłano także do Barbary Skargi, ale odmówiła udziału w zjeździe, przysyłając kasetę wideo ze swoją wypowiedzią (patrz niżej). Nieprawdą jest, że osoby te należały do jednego nurtu, w którym dominowały szeroko rozumiany pozytywizm i filozofia analityczna. Wolniewicz i Kmita nigdy nie uważali się za pozytywistów lub filozofów analitycznych, a referat Ziembińskiego dotyczył pogranicza etyki i filozofii prawa, i był wygłoszony bez odwoływania się do jakiegokolwiek stanowiska filozoficznego. Biorąc pod uwage zaproszenie Kołakowskiego i Skargi, różnorodność byłaby jeszcze większa, gdyby mogli (lub chcieli) oni przyjechać do Torunia, niż przy ostatecznym kształcie grupy referentów ogólnych. Cztery referaty były problemowe (Hiż, Kmita, Wolniewicz, Ziembiński), a tylko jeden dotyczył historii filozofii analitycznej, w tym przypadku polskiej. Istotnie, wśród tego grona nie było ani tomisty, ani fenomenologa, ale opinia p. Nawracały--Urban o zafałszowaniu pozycji ,innych nurtów” jest wysoce niestosowna. Członkowie Komitetu Programowego najwyraźniej uznali, że taki wybór referentów ogólnych jest reprezentatywny dla obrazu współczesnej filozofii polskiej. Jak jeszcze o tym wspomnę dalej, nasz wybór był kwestionowany nie tylko przez szkołę lubelską. Przy okazji sprostuję uwagę autorki, że Wójcicki zarzucił polskiej filozofii powojennej odwrócenie się od prawdy - ponieważ skierował tę uwagę pod adresem marksistów, nie wszystkich zresztą. Zapewne sekcje były niejednorodne, tematyka rozproszona i brakowało czasu na dłuższe dyskusje. Trudno tego jednak uniknąć przy 700 referatach, 32 sekcjach i 6 dniach obrad. Tak jest przy okazji każdego kongresu rozmiarami porównywalnego z toruńskim. Był on oceniany rozmaicie (stosowne wypowiedzi można bez kłopotu znaleźć w Internecie), np. Anna Zeidler-Janiszewska uznała, że brakło rozliczenia z marksizmem (już wtedy uznawano to za stratę czasu, przynajmniej na takim spotkaniu), Michał Heller ubolewał nad marnym stanem filozofii przyrody w Polsce, a Barbara Skarga (we wspomnianej wypowiedzi, emitowanej w trakcie zjazdu) bardzo zdecydowanie wytykała zbytnie podkreślanie wartości szkoły lwowsko-warszawskiej. To, że nikt nie widział w różnorodności ocen niczego zdrożnego czy nagannego, świadczy, że filozofia polska dość szybko doszła do równowagi po okresie gry z władzą i jej ideologicznymi eksponentami.

Sprawa przesłania od Jana Pawła II wyglądała tak. Komitet Programowy na wniosek Jerzego Perzanowskiego wystosował zaproszenie do Karola Wojtyły jako filozofa polskiego i członka honorowego Polskiego Towarzystwa 
Filozoficznego. Stępień nie musiał więc przypominać o tym, że Jan Paweł II należy do polskiej społeczności filozoficznej, ponieważ dobrze o tym wiedzieliśmy i na tej podstawie wystosowaliśmy rzeczone zaproszenie. Papież przekazał odpowiedź, którą przeczytał bp A. Suski. Gdy hierarcha zaczął odczytywać list, duchowni zasiadający w prezydium ceremonii otwarcia powstali z miejsc, a za nimi to samo uczyniła część obecnych na sali. Jedni zrobili to niejako automatycznie, inni zapewne z przekonania, że tak należy postapić. Siedziałem obok Hiża, który był dość zdziwiony, a nawet zniesmaczony zachowaniem się tych, którzy wstali dla wysłuchania słów głowy Kościoła katolickiego. W moim odczuciu była to próba narzucenia ze strony duchownych własnego stylu bycia osobom, które niekoniecznie go podzielały. Ocena Stępnia, że zjazd toruński nie wypełnił wielkiego zadania wskazanego w przesłaniu Jana Pawła II, czyli powołania do służby Prawdzie, nasuwa takie oto spostrzeżenia. Po pierwsze, nie wiadomo, czy w liście papieża do zjazdu była mowa o „prawdzie” czy o „Prawdzie” (nic na ten temat nie wynikało z dźwięku), a nawet jeśli o tej drugiej, to czy użycie dużej litery wskazywało na to, co Stępień rozumie przez takową pisownię, czy też nawiązywało do platońskiej triady Dobra, Piękna i Prawdy. Po drugie, również z czysto praktycznego punktu widzenia uczestnicy zjazdu nie bardzo mogli wypełnić owo wielkie zadanie, skoro zostało im wskazane w dniu otwarcia obrad. Po trzecie, przy całym szacunku dla papieskich słów, wszakże potraktowanych przez większość filozofów obecnych w Toruniu jako wyraz podziękowania za pamięć i zaproszenie, czasy, w których z góry wskazywano wielkie zadania filozofii, były w 1995 r. już minione, wprawdzie nie od tak dawna, ale już od kilku dobrych lat. Być może szkoła lubelska potrzebuje takowych instrukcji, ale niech nie rozszerza ich poza swój krąg. Każdy ma oczywiście prawo oceniać innych ze swojego punktu widzenia, a w filozofii jest to praktyka notoryczna. Być może polscy filozofowie (czy też wielu z nich) poszukiwali prawdy, a nie Prawdy w rozumieniu Stępnia, być może tej drugiej, ale nie do końca skutecznie, a być może innej Prawdy. M. Nawracała-Urban niemal perfekcyjnie zademonstrowała stronniczość środowiska, z jakim jest związana. Filtrem jej ocen, dotyczących zjazdów w Lublinie, Krakowie i Toruniu, stały się wypowiedzi (z jednym wyjątkiem, niezbyt odległym od głównego nurtu) członków szkoły lubelskiej, i tylko one. Pewnie jest to droga ku Prawdzie, ale niekoniecznie ku prawdzie. Zadanie, aby respektować pluralizm w filozofii, jest być może niewielkie w porównaniu do służby Prawdzie w rozumieniu szkoły lubelskiej, ale jednak przedstawia jakąś wartość, nader cenioną przez polskie środowisko filozoficzne. Zjazd toruński i dwa kolejne były bardzo wyraźną demonstracją w tym względzie.

Antoni B. Stępień kończy swoje hasło o marksistowskim materializmie następującym sformułowaniem (t. 1, s. 64): 
Wyłączną racją przyjęcia tej [marksistowskiej - J.W.] perspektywy wyzwolenia człowieka [...] jest arbitralne założenie systemowe filozofii, która - wywodząc się z okresu scjentystycznego zafascynowania naukami szczegółowymi - głosi się ,jedynie naukową”.

Sformułowanie to znajduje sięjuż w książce Wobec filozofii marksistowskiej, s. 59. M.A. Krąpiec pisze w tym zbiorze („Dialog?”, s. 12, 18):

Jest tylko jeden system filozoficzny mający za przedmiot konkretny byt realnie istniejący (jako analogicznie istniejący); jest to filozofia klasyczna w swej wersji „tomistycznej”, egzystencjalnej. [...].

Jest możliwe i zasadniczo praktykowane [...] rozwiązywanie ważnych i doniosłych problemów w kontekście filozofii klasycznej (tomizmu egzystencjalnego) [...]. I taka wydaje się droga jedynie prowadząca do celu - prawdy. Nie jest jednak jakieś „alternatywne” rozwiązanie, albowiem nie ma alternatywnych prawd przy zastosowaniu racjonalnej metody filozofowania mającej na celu ostatecznie wyjaśnić istniejącą rzeczywistość świata i człowieka.

Celowo opuściłem fragmenty (są na miejscach dwóch ostatnich zaznaczeń przez [...]) kontrastujące tomizm egzystencjalny z marksizmem jako ,alternatywą", mające sens w kontekście dialogu, którego dotyczy cały zbiór Wobec filozofii marksistowskiej. W rezultacie otrzymujemy przesłanie leżące u podstaw PEF i jeszcze bardziej Encyklopedii, mianowicie o jedyności tzw. filozofii klasycznej na drodze ku prawdzie (czy nawet Prawdzie), a także jako sposobu myślenia dającego podstawy dla ostatecznego miernika wartości wszelakich innych poglądów filozoficznych. Łatwo zauważyć strukturalne lub, jeśli ktoś woli, systemowe podobieństwo stanowiska marksistowskiego i szkoły lubelskiej, w szczególności polegające na tym, że oba są, by tak rzec, pochwalnie samozwrotne, i jako takie głoszone od wewnątrz, ale z niewielkim wsparciem zewnętrznym (jeśli chodzi o marksizm obecnie, bo drzewiej było inaczej, natomiast tzw. filozofia klasyczna, polska i niepolska, ciagle pozostaje we własnych opłotkach, tak jak to jest od dłuższego czasu; nic też nie świadczy o tym, jakoby ta sytuacja miała się zmienić w przewidywalnej przyszłości). Autoreferencyjne samochwalstwo nie jest bynajmniej dystynktywną cechą tylko tych dwóch stanowisk, aczkolwiek w przypadku neotomizmu (zwłaszcza lubelskiego) jest (w przypadku marksizmu trzeba powiedzieć „było”) głoszone wyjątkowo agresywnie. Ta postawa doprowadziła Encyklopedię do znacznej deformacji obrazu filozofii polskiej, w każdym razie współczesnej, której poznaniu ma służyć wedle deklarowanych, ale niezupełnie zrealizowanych intencji. 


\section{Dodatek}

Oto trzy cytaty (na razie bez wskazania źródeł i autorów):

(a) [...] etyka znajduje swój fundament w antropologii i ostatecznie w metafizyce, w której trzeba znaleźć definitywne wyjaśnienie moralności. Taka analiza prowadzi do stwierdzenia, że osoba i jej „personofania”, jest definitywnie „teofanią”. Gdyż zawdzięcza swoje istnienie Bogu Stwórcy. Ta ostateczna podstawa bycia osobą nie osłabia czy nie wchłania osoby jako osoby. Ujawnia tylko faktycznie, dlaczego osoba jest tym, kim jest, czyli osobą.

(b) [Jego antropologia] jest integralnym ujęciem prawdy o człowieku.

(c) Ale czy [...] uzyskaliśmy teorię człowieka, filozoficzną antropologię? Jeślibyśmy przez antropologię filozoficzną rozumieli taką teorię człowieka, która została skonstruowana przez filozoficzną analizę uniesprzeczniającą byt ludzki w kontekście jego istotnych i zasadniczych operacji ludzkich - to trzeba dojść do wniosku negatywnego.

Wszystkie fragmenty (a)-(c) dotyczą tego samego tematu, mianowicie antropologii filozoficznej Karola Wojtyły, przy czym dwa pierwsze, napisane przez s. Z. Zdybicka, pochodzą z Encyklopedii (t. 2, odpowiednio s. 330 i 828), natomiast (c) jest wyjęty z artykułu o. M.A. Krąpca, „Analecta Cracoviensia” 5-6 (1973-1974), s. 57 (tom ten poświęcony jest m.in. dyskusji nad książką K. Wojtyły Osoba i czyn, wydanej w 1969 r.). Łatwo zauważyć, że w (a) i (b) antropologia Wojtyły jest integralna, natomiast w (c) nie jest ona filozoficzną teorią człowieka, a więc jest tylko fragmentaryczna, co zresztą Krapiec wyraźnie podkreśla w przywołanym tekście.

Zdybicka i Krąpiec są czołowymi postaciami lubelskiej szkoły filozoficznej, a ten drugi autor jej, jak wiemy, założycielem i głównym filarem. Rzecz oczywiście nie w tym, że wszyscy, nawet należący do tej samej szkoły filozoficznej, mają tak samo oceniać myśl filozoficzną Wojtyły. W samej rzeczy, we wspomnianej dyskusji padło sporo argumentów krytycznych, np. zastrzeżeń Stępnia w kwestii pojęcia świadomości stosowanego w książce Osoba i czyn, w filozofii człowieka późniejszego papieża, wówczas kardynała i metropolity krakowskiego. W debacie brała udział także Zdybicka, a jej ocena różniła się od opinii Krąpca. Można więc powiedzieć, że hasła w Encylopedii o Wojtyle napisała mniej więcej w takim duchu, w jakim wypowiedziała się na łamach „Analecta Cracoviensia”. Jest też godne podkreślenia, że dyskusja w Krakowie miała charakter otwarty i bez taryfy ulgowej dla kard. Wojtyły, o co zresztą sam apelował w swym słowie wstępnym. Krytyka Krąpca (podobnie jak inne zastrzeżenia) adresowana do autora książki Osoba i czyn została całkowicie pominięta w Encyklopedii, a zacytowany artykuł z „Analecta Cracoviensia” nie znalazł się w ogóle w bibliografii, chociaż jeden z tekstów tam zamieszczo- 
nych jest wspomniany. Porównując stosunek Encyklopedii do etyki niezależnej Kotarbińskiego i do antropologii filozoficznej Wojtyły, łatwo dostrzeżmy różnicę w traktowaniu tego, co szkoła lubelska uważa za własne, i tego, co jest jej obce, głównie ze względów światopoglądowych. I to właśnie powoduje, że Encyklopedia oferuje nowy wspaniały świat filozofii polskiej, ale poprawiony wedle własnego interesu ideowego. Dlatego wypada zalecić daleko idąca ostrożność przy korzystaniu z tego skądinąd ambitnego dzieła. 